\title{
Co-Occurrence of Ochratoxin a and Aflatoxins in Maize (Zea Mays) and Their Associated Health Risk Estimations in Some Selected Regions (Different Agro-ecological Zones) of Ghana
}

Nii Korley Kortei ( $\square$ nkkortei@uhas.edu.gh )

University of Health and Allied Sciences

Theophilus Annan

Council for Scientific and Industrial Research- Food Research Institute

Vincent Kyei-Baffour

Council for Scientific and Industrial Research- Food Research Institute

Edward Ken Essuman

University of Health and Allied Sciences

Harry Okyere

Council for Scientific and Industrial Research- Crops Research Institute

Clement Okraku Tettey

University of Health and Allied Sciences

\section{Research Article}

Keywords: Ochratoxin A, aflatoxins, Ghana, toxigenic fungi, maize, cereals, HPLC-FLD

Posted Date: August 17th, 2021

DOI: https://doi.org/10.21203/rs.3.rs-795124/v1

License: (c) (1) This work is licensed under a Creative Commons Attribution 4.0 International License.

Read Full License 


\section{Abstract}

This study aimed at estimating ochratoxin A (OTA) and aflatoxin (AF) levels above international (European Food Safety Authority, EFSA) and local (Ghana Standards Authority, GSA) standards as well as the health risks associated with the consumption of maize $(n=180)$ sampled from six (6) regions (Upper East, Northern, Ashanti, Eastern, Central, and Western) representing the agro-ecological zones of Ghana. Ochratoxins, total aflatoxins $\left(\mathrm{AF}_{\text {Total }}\right)$, and the integral aflatoxins $\left(\mathrm{AFB}_{1}, \mathrm{AFB}_{2}, \mathrm{AFG}_{1}\right.$, and $\left.A F G_{2}\right)$ were measured with High-Performance Liquid Chromatography (HPLC) with a Fluorescence detector. Risk assessments were also conducted using models prescribed by the Joint FAO/WHO Expert Committee on Additives (JECFA). The general trend of occurrence of the aflatoxins was in decreasing order of $A_{F} B_{1}>$ $A F B_{2}>A F G_{1}>A F G_{2}$ and were in the ranges of $0-337 \mu \mathrm{g} / \mathrm{kg}, 0-101.00 \mu \mathrm{g} / \mathrm{kg}, 0-24.80 \mu \mathrm{g} / \mathrm{kg}$, and 0-5.51 $\mu \mathrm{g} / \mathrm{kg}$ respectively. The aggregated aflatoxins $\left(\mathrm{AF}_{\text {Total }}\right)$ were in the range of $0-441.02 \mu \mathrm{g} / \mathrm{kg}$. While ochratoxins (OTA) levels ranged between $0-97.51 \mu \mathrm{g} / \mathrm{kg}$. There were significant $(p<0.05)$ differences observed in all categories of the tested samples. Out of the 180 samples analyzed for total aflatoxins $\left(\mathrm{AF}_{\text {Total }}\right), 131 / 180$ tested positive and $127(70.50 \%)$ exceeded the limits of EFSA and ranged $4.27-441.02 \mu \mathrm{g} / \mathrm{kg}$. While for GSA, $116(64.44 \%)$ of samples exceeded this limit and ranged between $10.18-441.02 \mu \mathrm{g} / \mathrm{kg}$. For OTA, $103 / 180$ tested positive and $94(52.22 \%)$ of samples between the range $4.00-97.51 \mu \mathrm{g} / \mathrm{kg}$ exceeded the tolerable limit of the EFSA, whereas $89(49.44 \%)$ and were in the range of $3.30-97.51 \mu \mathrm{g} / \mathrm{kg}$ exceeded the limits of GSA. Risk assessment values for total aflatoxins $\left(\mathrm{AF}_{\mathrm{Total}}\right)$ ranged between 50-1150 $\mathrm{ng} / \mathrm{Kg}$.BW/day, 0.4-6.67, 0-0.0323 ng aflatoxins $\mathrm{kg}^{-1}$ bwday $^{-1}$ and 1.62-37.15 for Estimated Daily Intake (EDI), Margin of Exposure (MOE), Average Potency, and Cancer Risks respectively. Likewise, ochratoxin (OTA) values were in the ranges of $8.6 \times 10^{-3}-450 \mathrm{ng} / \mathrm{Kg} . \mathrm{bw} /$ day, $0.05-2059.97,0-0.0323 \mathrm{ng}$ ochratoxins $\mathrm{kg}^{-1}$ bwday ${ }^{-1}$ and $2.78 \times 10^{-4}-14.54$. It was deduced that the consumption of maize posed adverse health effects on all age categories of people from some of the locations studied because all calculated MOE values were less than 10,000 respectively for aflatoxins and ochratoxins.

\section{Introduction}

Maize (Zea mays $L$ ), a principal cereal extensively consumed ${ }^{1}$ around the globe is exceedingly prone to fungal infection by many toxigenic fungal species subsequently leading to mycotoxins production 2,3 due to its ideal nutrient composition ${ }^{4}$. This situation is particularly distressing since maize (Zea mays) accounts for $40 \%$ of the cereal production in Sub-Saharan Africa (SSA), where more than $80 \%$ is used as food ${ }^{5}$. The crop provides at least $30 \%$ of the total calorie intake of people in Sub-Saharan Africa Maize is consumed as a staple in the African region where intake ranges from 52 to $450 \mathrm{~g} /$ person/day ${ }^{1,6}$ and so is an easy channel for mycotoxin contamination.

Mycotoxins which are natural toxins from fungi, contaminate maize grains and render them potentially dangerous. Mycotoxins represent one of the main global foodborne risks for human health are considered an important issue in the situation of food safety, due to their acute and chronic toxic effects 
on animals and humans ${ }^{7,8}$. Noteworthy mycotoxins of maize include aflatoxins (AFs), ochratoxin $A$ (OTA), and Fumonisins (FM) ${ }^{9-11}$. Attendant contaminations could either be single or occur in multiple combinations with other mycotoxins.

Ochratoxins are fungal metabolites produced from the growth of some notable species including Aspergillus ochraceus, A. carbonarius, A. niger, and Penicillium verrucosum. Ochratoxins occur in A, B, C, and $D$ types of which the most common and toxic type is Ochratoxin A (OTA). OTA is assumed to be one of the five most important mycotoxins in agriculture ${ }^{12}$. Although not well known in Africa and the world at large compared to aflatoxins, ochratoxins are described as one of the most commonly occurring mycotoxins (fungal toxins) in the world due to their presence in a wide variety of foodstuffs such as potatoes, pulses, nuts, spices coffee, cacao, beer, and wine ${ }^{10}$. Nonetheless, notable among the main foodstuffs are cereals and cereal products, which constitute $60 \%$ of its total exposure to man and animals according to ${ }^{13}$ (JECFA).

The toxicological profile of OTA has been investigated and reviewed expansively in numerous studies ${ }^{14-}$ 19. In summary, these studies showed that OTA is nephrotoxic, hepatotoxic, neurotoxic, teratogenic, mutatoxic, immunotoxic and cause blood-brain barrier damage in various animals and humans, with renal toxicity and carcinogenesis being the significant adverse effects. There is limited evidence of OTAassociated chronic kidney disease in humans ${ }^{12}$. Ochratoxins $A(O T A)$ is aptly classified as a possible human carcinogen (2B agent) according to the International Agency for Research on Cancer (IARC) ${ }^{12,20}$.

Aflatoxins are also fungal metabolites produced by strains of Aspergillus flavus and A. parasiticus. They are by and large the most well-known mycotoxin owing to their persistence in the environment and also the ubiquitous nature of their contaminants. Aflatoxins occur in five different types; aflatoxin B1, B2, G1, G2, and M1 produced primarily in cow milk by cow-eating contaminated silage. Prolonged consumption of aflatoxins has been reported to cause impaired immune function, hepatotoxicity, neurotoxicity, malnutrition and stunted growth in children, teratogenic, mutagenic disabilities, and eventual death ${ }^{21,22}$. The International Agency for Research on Cancer (IARC) and the Joint FAO/WHO Expert Committee on Food Additives (JECFA) named it as a class 1 carcinogen due to its high potency ${ }^{23,24}$.

The evidence that mycotoxins can have adverse health effects on humans and animals has led many countries to set up standards for maximum levels of total aflatoxins and ochratoxins in food products intended for both human and animal consumption ${ }^{25}$. These permissible levels are almost excruciating especially in developing countries in Sub-Saharan Africa. Bankole and Adebanjo ${ }^{26}$ noted when the worldwide directive of mycotoxins in food is under consideration, the impact seems to be greater on low to medium-income countries. It was projected that enforcement of strict regulations regarding aflatoxin contamination by the European Union would result in the rejection of $64 \%$ of imports of cereals, dried fruits, and nuts from African countries with an estimated trade loss per year of approximately US $\$ 670$ million ${ }^{26}$. 
In addition to setting regulatory limits for mycotoxins, it is also imperative to conduct health risk assessments in the population due to dietary exposure. A low-dose extrapolation approach introduced by the Joint FAO/WHO Expert Committee on Food Additives (JECFA) in 1997 and the margin of exposure (MOE) method proposed at the 64th JECFA meeting in $2005^{27}$ were both recommended and have been widely used worldwide ${ }^{28,29}$ to assess the risk of dietary exposure to mycotoxins.

There is a paucity of data on ochratoxin A contamination in foodstuffs in Ghana. The objectives of this study, therefore, were to assess the levels of ochratoxin $A$ and aflatoxins combination in maize samples as well as their associated health risk estimations in six (6) different regions representative of the different agro-ecological zones of Ghana.

\section{Materials And Methods}

\section{Sample collection}

To collect a representative data set, we first obtained the list of villages in each district from the Regional Directorate of the Ministry of Agriculture. From each district, an average of 5 villages (Table 1 ) was then randomly selected. The maize sellers in each market were conveniently sampled where about one kilogram $(1 \mathrm{~kg})$ of raw maize samples were purchased concurrently from July to December 2020 . Five hundred (500) grams each of maize samples were fetched and kept in sterile bags in ice chests and sent to the laboratory within the same day in a vehicle where they were stored in a deep freezer at $-20^{\circ} \mathrm{C}$ until ready for chemical analysis ${ }^{30}$.

Table 1

Geographical locations and some attributes of the origin of samples

\begin{tabular}{|llllll|}
\hline Region & $\begin{array}{l}\text { No. of } \\
\text { samples }\end{array}$ & $\begin{array}{l}\text { Agro-ecological } \\
\text { zones }\end{array}$ & $\begin{array}{l}\text { Rainfall } \\
(\mathbf{m m})\end{array}$ & $\begin{array}{l}\text { Temperature } \\
\left({ }^{\circ} \mathrm{C}\right)\end{array}$ & Coordinates \\
\hline $\begin{array}{l}\text { Upper } \\
\text { East }\end{array}$ & $30 / 180$ & Sudan Savannah & $800-1000$ & 28.3 & $10.7082 \circ \mathrm{N}, 0.9821 \circ \mathrm{W}$ \\
\hline Northern & $30 / 180$ & Guinea Savannah & $\begin{array}{l}1000- \\
1200\end{array}$ & 27.9 & $9.5439 \circ \mathrm{N}, 0.9057 \circ \mathrm{W}$ \\
\hline Ashanti & $30 / 180$ & Transitional & $\begin{array}{l}1200- \\
1400\end{array}$ & 25.9 & $6.7470 \circ \mathrm{N}, 1.5209 \circ \mathrm{W}$ \\
\hline Eastern & $30 / 180$ & Semi-deciduous & $\begin{array}{l}1400- \\
1900\end{array}$ & 25.9 & $6.2374 \circ \mathrm{N}, 0.4502 \circ \mathrm{W}$ \\
\hline Central & $30 / 180$ & $\begin{array}{l}\text { Coastal } \\
\text { Savannah }\end{array}$ & $\begin{array}{l}1400- \\
1600\end{array}$ & 26.7 & $5.5608 \circ \mathrm{N}, 1.0586 \circ \mathrm{W}$ \\
\hline Western & $30 / 180$ & Rain Forest & $\begin{array}{l}1800- \\
2000\end{array}$ & 25.9 & $5.3902 \circ \mathrm{N}, 2.1450 \circ \mathrm{W}$ \\
\hline
\end{tabular}




\section{Determination of Ochratoxins A}

\section{Chemicals and standards}

The analytical standard of OTA was supplied by Sigma-Aldrich (St. Louis, MO, USA). All solvents used for the preparation of the mobile phase were HPLC grade and obtained from Merck (Darmstadt, Germany). Methanol and hexane used for extraction were of analytical grade supplied by Sigma-Aldrich. All homogenized mixtures and eluates were filtered through Whatman no. 4 and $0.45 \mathrm{~mm}$ membrane filters respectively (Whatman plc, Maidstone, UK). De-ionized water was obtained with a Millipore Elix Essential purification system (Bedford, MA, USA). OCHRA PREP immunoaffinity columns were supplied by RBiopharm, Rhone limited, and used for SPE and cleanup. These columns have a concentration capacity of $100 \mathrm{ng} \mathrm{mL}^{-1}$ with at least $90 \%$ recovery. Phosphate-buffered saline (PBS) was prepared by dissolving PBS tablets (Sigma-Aldrich) in distilled water. Sodium chloride ( $\geq 99.0 \%)$ was sourced from SigmaAldrich. Six-point calibration was made using the pure Ochratoxin A standard at concentrations of 5 $\mu \mathrm{g} / \mathrm{kg}, 10 \mu \mathrm{g} / \mathrm{kg}, 15 \mu \mathrm{g} / \mathrm{kg}, 20 \mu \mathrm{g} / \mathrm{kg}, 25 \mu \mathrm{g} / \mathrm{kg}$ and $30 \mu \mathrm{g} / \mathrm{kg}$. Linearity was accepted at 0.99 or $99 \%$ for the regression curve (CEN official method EN14123 ${ }^{33}$ ).

\section{Determination of Ochratoxin}

Ochratoxin A was determined based on CEN official method EN14123 (2007) ${ }^{32}$. About $500 \mathrm{~g}$ each of maize was sampled by thoroughly mixing and heaping the whole batch into a cone. Using cardboard, the heap was divided into four equal parts. Two opposite parts were mixed, and the remaining two parts were packed, and the process repeated until a representative $500 \mathrm{~g}$ sample was achieved and ground into fine maize powder and groundnut slurry. Exactly $25 \mathrm{~g}$ of powdered or slurred samples were extracted with $5 \mathrm{~g}$ sodium chloride and $200 \mathrm{ml}$ methanol in distilled water in a ratio of 4:1 respectively. Hexane $(100 \mathrm{ml})$ was added to the groundnut mixture and samples homogenized for $3 \mathrm{~min}$ (i.e., $3000 \mathrm{rpm}$ for $2 \mathrm{~min}$ and at $3500 \mathrm{rpm}$ for $1 \mathrm{~min}$ ). The groundnut mixture generated two organic layers (the hexane upper layer and methanol lower layer). The lower methanol layer of the groundnut mixture and the maize mixture was filtered through Whatman number 4 filter paper. Ten milliliters $(10 \mathrm{ml})$ of filtrates were used for Ochratoxin A solid-phase extraction and cleanup. Exactly $150 \mathrm{ml}$ of phosphate buffer saline (PBS) was added to 10 $\mathrm{ml}$ of filtrates and the mixture stirred. Immunoaffinity columns specific for Ochratoxin A were preconditioned and antibodies in the column activated by eluting $10 \mathrm{ml}$ of phosphate buffer saline through columns at a flow speed of $3 \mathrm{ml} \mathrm{min}{ }^{-1}$. Exactly $50 \mathrm{ml}$ of the $160 \mathrm{ml}$ filtrate-PBS mixture was loaded onto the pre-conditioned immunoaffinity columns specific for Ochratoxin A and allowed to drain by gravity. The columns were washed three times with $5 \mathrm{ml}$ PBS and allowed to elute at a flow rate of $5 \mathrm{ml} \mathrm{min}{ }^{-1}$. Using a vacuum pump, the air was blown through the columns to get rid of all wash solvent molecules. Ochratoxin A was eluted in two steps into a $5 \mathrm{ml}$ volumetric flask by first eluting with $1 \mathrm{ml}$ of methanol (highest grade) followed by another $1 \mathrm{ml}$ of methanol after one minute. Air was blown through the column to collect all eluates. Aqueous acetic acid (1\%) was used to make up a volume of eluates to $4 \mathrm{ml}$ and eluates vortexed after which $2 \mathrm{ml}$ was pipetted into HPLC vials for quantification. 


\section{HPLC parameters}

Agilent high-performance liquid chromatography system (HPLC 1260 infinity series) with a quaternary pump and fluorescence detection was used for OTA quantification. Data acquisition and quantification were done using Chem station (Open lab edition). The Agilent HPLC equipped with a fluorescence detector was set at an excitation wavelength of $333 \mathrm{~nm}$ and an emission wavelength of $467 \mathrm{~nm}$ and the column compartment temperature regulated at $30^{\circ} \mathrm{C}$. The mobile phase was a mixture of $5 \mathrm{mM}$ sodium acetate with acetic acid ( $\mathrm{pH}$ 2.4): methanol: acetonitrile at ratios of 40:30:30, respectively, and isocratic delivery mode employed at a flow rate of $1 \mathrm{ml} \mathrm{min}^{-1}$ with an injection volume of $10 \mu \mathrm{l}$. The run time was set at 10 minutes (CEN official method EN14123 ${ }^{33}$ ).

\section{Aflatoxins Determination}

\section{Extraction of samples}

$\mathrm{AFB}_{1}, \mathrm{AFB}_{2}, \mathrm{AFG}$, and $\mathrm{AFG}_{2}$ were extracted from samples according to the European Committee for Standardization (CEN) official method EN14123 ${ }^{33}$ for aflatoxin extraction. Methanol in water (200 ml) (8 $+2)$ and $5 \mathrm{~g} \mathrm{NaCl}$ were used to extract $25 \mathrm{~g}$ of sample. Hexane $(100 \mathrm{ml})$ was added to samples containing more than $50 \%$ fat. The mixture was homogenized for $3 \mathrm{~min}$ at $3000 \mathrm{rpm}(2 \mathrm{~min})$ and 3500 $\mathrm{rpm}(1 \mathrm{~min})$. The extracts were filtered and $10 \mathrm{ml}$ of filtrate added to $60 \mathrm{ml}$ of phosphate buffer saline (PBS) for solid-phase extraction using a pre-conditioned immunoaffinity column specific for $\mathrm{AFB}_{1}, \mathrm{AFB}_{2}$, $\mathrm{AFG}_{1}$, and $\mathrm{AFG}_{2}$. The $70 \mathrm{ml}$ filtrate-PBS mixture was loaded onto the pre-conditioned column and allowed to elute by gravity at a flow rate of $1 \mathrm{ml} \mathrm{min}^{-1}$. This was followed by a cleanup with $15 \mathrm{ml}$ distilled water at a flow rate of $5 \mathrm{ml} \mathrm{min}{ }^{-1}$. Aflatoxins were eluted in two steps into a $5 \mathrm{ml}$ volumetric flask with $0.5 \mathrm{ml}$ followed by $0.75 \mathrm{ml}$ of methanol (HPLC grade) and allowed to elute by gravity. Deionized water was used to make up a volume of eluates to $5 \mathrm{ml}$ and eluate vortexed and $2 \mathrm{ml}$ pipetted into HPLC vials for quantification.

\section{HPLC parameters}

Injection volume: $10 \mu \mathrm{l}$ flow rate: $1 \mathrm{~mL} / \mathrm{min}$, column temperature: $35^{\circ} \mathrm{C}$, excitation wavelength: $360 \mathrm{~nm}$, emission wavelength: $440 \mathrm{~nm}$, mobile phase composition: water/acetonitrile/ $\mathrm{MeOH}(65: 15: 20 \mathrm{v} / \mathrm{v} / \mathrm{v})$, post-column derivatization: Kobra cells. HPLC Column Specification Spherisorb ODS1- Excel

$(4.6 \mathrm{~mm} \times 25 \mathrm{~cm}), 5 \mu \mathrm{m}$ particle size, 250 A pore size

LOD = Limit of detection

$\mathrm{LOQ}=$ Limit of quantification

$\mathrm{ACN}=$ Acetonitrile

$\mathrm{MeOH}=$ Methanol 
LOD calculation $=3$ * standard deviation/slope.

LOQ calculation $=3 \times$ LOD

Supplier of Column R- Biopharm, Block 10 campus, West Scotland

Science Park, Acre Road, Glasgow, Scotland G20 OXA.

\section{Analysis of samples}

The aflatoxins (by Aspergillus flavus and A. parasiticus) levels in the samples were determined according to the CEN official method EN14123 ${ }^{33}$ by High-Performance Liquid Chromatography HPLC (Agilent 1260 Series, OpenLab software, X-bridge column) $(250 \mathrm{mmx} 4.6 \mathrm{~mm}$, i.d., $5 \mu \mathrm{m})$, USA with fluorescence detector and post-column derivatization using Kobra cells to generate bromine electrochemically at the CSIR- Food Research Institute, Ghana.

LOD for Ochratoxins was $0.83 \mu \mathrm{g} / \mathrm{kg}$ while LOQ recorded $2.49 \mu \mathrm{g} / \mathrm{kg}$ (Table 2)

Table 2

Limits of Detection (LOD) and Quantification (LOQ) of ochratoxins (OTA) and aflatoxins $\mathrm{AFB}_{1}, \mathrm{AFB}_{2}, \mathrm{AFG}_{1}$, $\mathrm{AFG}_{2}$, and Total aflatoxins $(\mu \mathrm{g} / \mathrm{kg})$ measured by HPLC

\begin{tabular}{|lll|}
\hline Aflatoxin & Limits & Amount $(\boldsymbol{\mu g} / \mathbf{k g})$ \\
\hline OTA & LOD & 0.83 \\
& LOQ & 2.49 \\
\hline AFB1 & LOD & 0.15 \\
\hline AFB2 & LOQ & 0.45 \\
\hline & LOD & 0.15 \\
\hline AFG1 & LOD & 0.45 \\
\hline & LOQ & 0.13 \\
\hline AFG2 & LOD & 0.13 \\
\hline \multicolumn{4}{|c}{ LOQ } & 0.39 \\
\hline LOD-Limit of Detection
\end{tabular}


LOD for AFB1, AFB2 was $0.15 \mu \mathrm{g} / \mathrm{kg}$, and $0.13 \mu \mathrm{g} / \mathrm{kg}$ for AFG1 and AFG2 while LOQ were 0.39 and 0.45 $\mu \mathrm{g} / \mathrm{kg}$ (Table 2).

\section{Limit of detection/quantification (LOD/LOQ)}

Limit of detection and quantification (LOD/LOQ) of the HPLC were estimated by making a calibration curve around the least standard used for spiking, $5 \mu / \mathrm{kg}$ (lowest concentration range of calibration curve). Blank did not produce any signal, so the LOD and LOQ were calculated as;

LOD $=3$ * standard deviation/slope. (1)

\section{$\mathrm{LOQ}=3$ * LOD. (2)}

\section{Measurement accuracy}

Spiking of pure aflatoxin standard solution was done to ensure measurement accuracy of the analysis.

Three levels of spiking were done at the lower, mid, and upper concentration range of the calibration curve concentrations ( $5 \mathrm{ppb}, 15 \mathrm{ppb}$, and $30 \mathrm{ppb}$ ). Spike volumes of pure standards were calculated as;

[Sample weight $(\mathrm{g})$ * spike concentration $(\mathrm{ppb})]$ / [Concentration of standard (ug/ml)]. (3)

Spike volumes were distributed evenly on aflatoxins free sample (blank) and the spiked sample analyzed for percentage recovery which was calculated as;

[(Concentration measured in spike - concentration measured in the blank) /(spiked amount)] * 100 (4)

\section{Measurement Precision}

Repeatability and intermediate precision analyses of an internal reference material (IRM) were used to ensure the measurement precision of the method. For repeatability analysis, 10 parallel extractions of the IRM were done by the same analyst at the same time using the same HPLC and the relative standard deviation among results calculated. For intermediate precision, 10 extractions of the IRM were done on different days by different analysts, and the relative standard deviation among results calculated. The relative standard deviations were calculated as; [Standard deviation/mean] * 100 (CEN official method EN14123 ${ }^{33}$ ).

\section{Required Performance Criteria for Accuracy and Precision}

Repeatability: Relative standard deviation among repeatable results should be less than $15 \%$.

Intermediate Precision: Relative standard deviation among results obtained under intermediate precision conditions should be less than $\mathbf{2 0 \%}$.

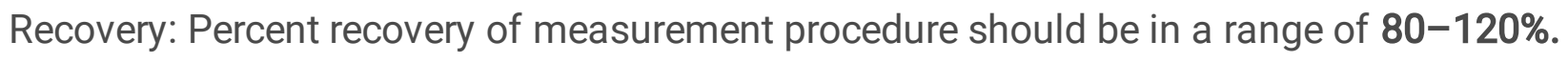


Limit of Detection: The limit of detection should be less than $1 \mathbf{u g} / \mathbf{k g}$ for all aflatoxins.

Limit of Quantification: The limit of Quantification should be less than $\mathbf{3} \mathbf{u g} / \mathbf{k g}$ for all aflatoxins.

Linearity: Linearity from the regression curve should be 0.99 (B1, B2, G1) and 0.98 (G2).

\section{Experimental Data}

Repeatability: Relative standard deviation was;

$B 1=5.5 \% ; B 2=6.7 \% ; G 1=7.4 \% ; G 2=12.1 \%$ and Total aflatoxins $=5.2 \%$.

Intermediate Precision (Reproducibility): Relative standard deviation was;

$B 1=13.2 \% ; B 2=13.4 \% ; G 1=13.7 \% ; G 2=12.2 \%$ and Total aflatoxins $=11.9 \%$.

Recovery: Percent recovery of measurement procedure was;

Low concentration: $B 1=107 \% ; B 2=87.2 \% ; G 1=113.4 \% ; G 2=112.8 \%$ and Total aflatoxins $=108.2 \%$

High concentration: B1 $=102.6 \% ; B 2=101.6 \% ; G 1=104.2 \% ; G 2=104.4 \%$ and Total aflatoxins $=103.3 \%$

Linearity: Linearity from regression curve was;

\section{$B 1=0.991 ; B 2=0.997, G 1=0.994 ; G 2=0.995$}

(CEN official method EN14123 ${ }^{33}$ )

Human risk assessment of exposure to total aflatoxins via consumption of cereals Exposure estimation

Estimated Daily Intake (EDI) was considered by using the mean quantities of mycotoxin (ochratoxins or aflatoxins) derived from the cereal samples, the number of samples consumed daily, and the average body weight. The EDI for mean aflatoxins was premeditated according to the following formula (5) and expressed in $\mu \mathrm{g} / \mathrm{kg}$ of body weight/day ( $\mu \mathrm{g} / \mathrm{kg}$ b.w/day) ${ }^{34,35}$.

$E D I=$ daily intake (food) $x$ mean level of mycotoxin

average bodyweight (5)

The daily intake of maize in Ghana according to MOFA-IFPRI (2020) in Kortei et al ${ }^{2}$ is approximately $0.107 \mathrm{~kg} /$ day $(39.3 \mathrm{~kg} / \mathrm{year})$.

The different age categories according to EFSA, ${ }^{36}$ and their corresponding estimated average weights in Ghana used in this study were done as follows; Infants- $2.9(2.5-3.2) \mathrm{Kg}^{37,38}$, Toddler - $9.8(7-12.6) \mathrm{Kg}$ 
39,40 (Worldbank.org), Children - $26(24-28) \mathrm{Kg}^{41,42}$, Adolescents- $46.25(38.5-54) \mathrm{Kg}{ }^{43}$, Adults- $60.7 \mathrm{Kg}$ 44.

\section{Cancer Risk Characterization for Aflatoxins and Ochratoxins}

Genotoxic compounds such as aflatoxins and ochratoxins have their risk assessments fittingly computed based on the Margin of Exposures (MOEs) approach, which was estimated by dividing the Benchmark dose lower limit (BMDL) for aflatoxins is $400 \mathrm{ngkg}^{-1}$ bwday $^{-1}$ by toxin exposure 23,45 .

Similarly, Benchmark dose lower limit (BMDL) for ochratoxins - $130 \mathrm{ngkg}^{-1}$ bwweek $^{-1} 46$ and $120 \mathrm{ngkg}^{-}$ ${ }^{1}$ bwweek $^{-1}{ }^{47}$ resulting in an average of $125 \mathrm{ngkg}^{-1}$ bwweek $^{-1}\left(17.86 \mathrm{ngkg}^{-1}\right.$ bwday $\left.^{-1}\right)$ by toxin exposure as expressed in Eq. (6).

$\mathrm{MOE}=$ Benchmark dose lower limit

EDI (Exposure) (6)

A public health alarm is raised in instances where MOEs are less than 10,000 , which implied that aflatoxin exposures above $0.4 \mathrm{\mu gkg}^{-1}$ bwday $^{-1}\left(400 \mathrm{ngkg}^{-1} \text { bwday }^{-1}\right)^{2,45}$.

Similarly, an assumption of MOEs less than 10,000 which implied that ochratoxin exposures above $0.01786 \mathrm{mgkg}^{-1}$ bwday $^{-1}\left(17.86 \mathrm{ngkg}^{-1} \text { bwday }^{-1}\right)^{46}$ was made.

Estimated Liver Cancer Risk due to Consumption of food samples.

The ingestion of aflatoxins likewise ochratoxins can be linked to the onset of liver cancer ${ }^{48,49}$. Therefore, liver cancer risk estimation for Ghanaian adult consumers was calculated for aflatoxins ${ }^{45}$. This involved estimating the population cancer risk per 100,000 which is a product of the EDI value and the average hepatocellular carcinoma (HCC) potency figure from individual potencies of Hepatitis B surface antigen (HBsAg) (HBsAg-positive and HBsAg-negative groups).

The JECFA ${ }^{50}$ estimated potency values for AF/OTA which corresponded to 0.3 cancers year $^{-1} 100,000^{-1}$ population $/ \mathrm{ngkg}^{-1}$ bwday $^{-1}$ (uncertainty range: $0.05-0.5$ ) in HBsAg-positive individuals and 0.01 cancers year ${ }^{-1} 100,000^{-1}$ population/ ngkg $^{-1}$ bwday $^{-1}$ (uncertainty range: 0.002-0.03) in HBsAg-negative individuals ${ }^{49}$ were adopted for this calculation. Also, the average $\mathrm{HBsAg}+$ prevalence rate of $7.74 \%$ (adult-8.36\%, 14.3\%-adolescents, 0.55\%-children) for Ghana 5152 was adopted and $92.26 \%(100-7.74 \%)$ was extrapolated for HBsAg-negative groups. Hence the average potency for cancer in Ghana was estimated as follows according to Eq. (7) as prescribed by ${ }^{49}$ and ${ }^{45}$ :

Average potency $=[0.03 \times \mathrm{HBsAg}-$ negative individuals in Ghana $]+[0.01 \times \mathrm{HBsAg}$ - positive individuals/prevalence rate in Ghana] (7)

\section{$(0.3 \times 0.077)+(0.01 \times 0.9226)$}


$=0.0323$ cancers per year per 100,000 population per ng aflatoxins/ochratoxins $\mathrm{kg}^{-1}$ bwday $^{-1}$.

Thus the Cancer risk was estimated using the following formula in Eq. (8) 2,45 :

Cancer risk $=$ Exposure $(E D I) \times$ Average potency $(8)$

The use of plants in the present study complies with international, national and/or institutional guidelines.

\section{Statistical Analysis}

The ochratoxins and aflatoxins concentrations were calculated using regression analysis from the curves generated from the standards of the ochratoxins/aflatoxins with Excel for Microsoft Windows (version 10). SPSS 22 (Chicago, USA) was used in the analysis of data. Descriptive analysis was performed to describe the concentration of ochratoxins/aflatoxins in maize samples by using the mean \pm standard deviation. Deterministic risk assessment model calculations for ochratoxins and aflatoxins dietary exposure (Estimated Dietary Intake), MOE values, Average potency, and cancer risk were calculated. The results are summarized as standard error, median, standard deviation, variance, skewness, standard error of skewness, kurtosis, and standard error of kurtosis and the mean values (range from the 25th percentile to the 75th percentile). Associations of the mycotoxins (AFTotal, AFB1, and Ochratoxins) were determined using Kendall's tau_b correlation test.

\section{Results}

Samples tested, produced good linearity or coefficients of correlations $\left(R^{2}>0.990\right)$ within the tested range. For the recovery analysis, samples previously tested to guarantee the nonappearance of studied mycotoxins were used in the validation procedure. For ochratoxins, the limit of detection was $0.83 \mu \mathrm{g} / \mathrm{kg}$ while the Limits of Detection for $A F B_{1}$ and $A F B_{2}$ likewise $A F G_{1}$ and $A F G_{2}$ ranged between $0.13-0.15$ $\mu \mathrm{g} / \mathrm{kg}$. The limit of Quantification for ochratoxins was $2.49 \mu \mathrm{g} / \mathrm{kg}$. Aflatoxins ranged between $0.39-0.45$ $\mu \mathrm{g} / \mathrm{kg}$ respectively for both (Table 2 ).

Out of a total of one hundred and eighty (180) samples tested, 131 test positive. The general trend of occurrence of the aflatoxins was in decreasing order of $A F B_{1}>A F B_{2}>A F G_{1}>A F G_{2}$ and were in the ranges of $0-337 \mu \mathrm{g} / \mathrm{kg}, 0-101.00 \mu \mathrm{g} / \mathrm{kg}, 0-24.80 \mu \mathrm{g} / \mathrm{kg}$, and $0-5.51 \mu \mathrm{g} / \mathrm{kg}$ respectively. The aggregated aflatoxins (AFtotal) were in the range of $0-441.02 \mu \mathrm{g} / \mathrm{kg}$. While for ochratoxins (OTA), 103 samples tested positive. OTA levels were also observed to be lesser than AFB1, AFB2 but more than AFG1 and AFG2 and ranged between $0-97.51 \mu \mathrm{g} / \mathrm{kg}$. There were significant $(p<0.05)$ differences observed in all categories of the tested samples.

For the Upper East region representing the Sudan Savanna zone (Fig. 1), the range of values was 0$106.18 \mu \mathrm{g} / \mathrm{kg}$ for Total aflatoxins. $32.84,30.35$ and $668.51 \mu \mathrm{g} / \mathrm{kg}$ were recorded from the summary statistics as mean, median and variance respectively, while 0.83 and 0.89 were recorded as the skewness 
and kurtosis respectively which implied a symmetrical and normally distributed data for Total Aflatoxins (AFtotal) (the distribution is not outside the range of normality) (Table 3.0). For ochratoxins (OTA), values of range $0-62.50 \mu \mathrm{g} / \mathrm{kg}$ were recorded. While $18.22,14.56$ and 371.75 represented the mean, median and variance. Skewness and Kurtosis were 0.77 and -0.50 respectively and implied the distribution produced fewer and less extreme outliers than does the normal distribution or were fairly symmetrical and lighttailed. There was a significant $(p<0.01)$ correlation between AFB1 and AF ${ }_{\text {Total }}$ in this data set $($ Table 3.1).

The Northern Region (Guinea Savanna) zone recorded a range of values of 0-285.31 for Total aflatoxins. Values of $48.93,25.09$ and $4214.84 \mu \mathrm{g} / \mathrm{kg}$ were recorded for mean, median and variance respectively while the skewness and kurtosis were 2.14 and 5.35 respectively and showed that the data set of Total aflatoxins $\left(\mathrm{AF}_{\text {Total }}\right)$ obtained in this zone was asymmetrical and heavy-tailed (Table 4.0). Ochratoxins (OTA), were within the range of $0-46.77 \mu \mathrm{g} / \mathrm{kg}$. Values of $14.14,6.70$ and $232.47 \mu \mathrm{g} / \mathrm{kg}$ were recorded as mean, median and variance respectively while 0.85 and -0.58 were obtained as Skewness and Kurtosis respectively which suggested a fairly symmetrical distribution and light-tailed. There were significant $(\mathrm{p}<$ 0.01) correlations established between AFB1 and $A F_{\text {Total }}$ as well as $A F_{\text {Total }}$ and OTA (Table 4.1)

Table 4.0

Statistical summary of data obtained from the Northern Region of Ghana

\begin{tabular}{|lllllll|}
\hline N samples (30) & AFB1 & AFB2 & AFG1 & AFG2 & AFTotal & OTA \\
\hline Mean & 36.65 & 9.67 & 2.14 & 0.47 & 48.93 & 14.14 \\
\hline Std. Error of Mean & 9.95 & 1.97 & 0.68 & 0.71 & 11.85 & 2.783 \\
\hline Median & 16.21 & 7.62 & 0.00 & 0.00 & 25.09 & 6.70 \\
\hline Std. Deviation & 54.50 & 10.83 & 3.72 & 0.93 & 64.92 & 15.25 \\
\hline Variance & 2970.10 & 117.25 & 13.80 & 0.88 & 4214.84 & 232.47 \\
\hline Skewness & 2.69 & 0.75 & 1.93 & 1.82 & 2.14 & 0.85 \\
\hline Std. Error of Skewness & 0.43 & 0.43 & 0.43 & 0.43 & 0.43 & 0.43 \\
\hline Kurtosis & 8.59 & -0.68 & 3.78 & 2.10 & 5.37 & -0.58 \\
\hline Std. Error of Kurtosis & 0.83 & 0.83 & 0.83 & 0.83 & 0.83 & 0.83 \\
\hline Minimum & 0.00 & 0.00 & 0.00 & 0.00 & 0.00 & 0.00 \\
\hline Maximum & 255.50 & 34.73 & 15.00 & 3.23 & 285.31 & 46.77 \\
\hline Percentiles 25 & 0.00 & 0.00 & 0.00 & 0.00 & 0.00 & 1.20 \\
\hline 50 & 16.21 & 7.62 & 0.00 & 0.00 & 25.09 & 6.70 \\
\hline 75 & 43.24 & 19.20 & 4.25 & 0.27 & 67.83 & 25.18 \\
\hline
\end{tabular}


Table 4.1

Associations of mycotoxins (AFB1, AFTotal and OTA) in maize from Northern Region

\begin{tabular}{|llll|}
\hline & AFB1 & AFTotal & OTA \\
\hline AFB1 & 1.00 & $0.907^{* *}$ & $0.569 * *$ \\
\hline AFTotal & 0.00 & 0.000 \\
\hline & 1.00 & $0.632^{\star *}$ \\
\hline OTA & & 0.00 \\
\hline$* \star$ Correlation is significant at the 0.01 level (2-tailed) \\
\hline
\end{tabular}

Total aflatoxins for the Ashanti region representing Transitional zones were within the range of 0-230.00 $\mu \mathrm{g} / \mathrm{kg}$, while the mean, median and variance recorded were $62.37,46.77$ and $4247.89 \mu \mathrm{g} / \mathrm{kg}$ respectively. The data set showed symmetrical and light-tailed as the skewness and kurtosis were 1.12 and 0.71 respectively (Table 5.0). Ochratoxins were also in a range of $0-76.05 \mu \mathrm{g} / \mathrm{kg}$. Mean, median and variances were $11.52,0.00$ and $403.94 \mu \mathrm{g} / \mathrm{kg}$ respectively with Skewness and Kurtosis of 1.70 and 2.5 suggesting the distribution is not outside the range of normality (Table 5.0). Significant $(p<0.01)$ correlations were established between AFB1 and $\mathrm{AF}_{\text {Total }}$ likewise $\mathrm{AF}_{\text {Total }}$ and OTA (Table 5.1). 
Table 5.0

Statistical summary of data obtained from the Ashanti Region of Ghana

\begin{tabular}{|lllllll|}
\hline N samples (30) & AFB1 & AFB2 & AFG1 & AFG2 & AFTotal & OTA \\
\hline Mean & 43.84 & 13.03 & 4.45 & 1.07 & 62.37 & 11.52 \\
\hline Std. Error of Mean & 9.32 & 2.36 & 1.04 & 0.35 & 11.90 & 3.67 \\
\hline Median & 27.51 & 12.47 & 0.00 & 0.00 & 46.77 & 0.00 \\
\hline Std. Deviation & 51.10 & 12.94 & 5.69 & 1.90 & 65.18 & 20.10 \\
\hline Variance & 2611.33 & 167.34 & 32.43 & 3.60 & 4247.89 & 403.94 \\
\hline Skewness & 1.58 & 0.67 & 0.98 & 1.73 & 1.12 & 1.75 \\
\hline Std. Error of Skewness & 0.43 & 0.43 & 0.43 & 0.43 & 0.43 & 0.43 \\
\hline Kurtosis & 2.32 & -0.37 & -0.24 & 2.10 & 0.71 & 2.50 \\
\hline Std. Error of Kurtosis & 0.83 & 0.83 & 0.83 & 0.83 & 0.83 & 0.83 \\
\hline Minimum & 0.00 & 0.00 & 0.00 & 0.00 & 0.00 & 0.00 \\
\hline Maximum & 188.87 & 45.84 & 18.63 & 6.73 & 230.00 & 76.05 \\
\hline Percentiles 25 & 1.42 & 0.00 & 0.00 & 0.00 & 1.42 & 0.00 \\
\hline 50 & 27.50 & 12.47 & 0.00 & 0.00 & 46.77 & 0.00 \\
\hline 75 & 62.17 & 22.23 & 10.20 & 2.16 & 95.93 & 25.98 \\
\hline
\end{tabular}

Table 5.1

Associations of mycotoxins (AFB1, AFTotal and OTA) in maize from Ashanti Region

\begin{tabular}{|llll|}
\hline & AFB1 & AFTotal & OTA \\
\hline AFB1 & 1.00 & $0.978^{* *}$ & $0.816^{* *}$ \\
\hline AFTotal & 0.00 & 0.00 \\
& 1.00 & $0.828^{* *}$ \\
\hline OTA & & 0.00 \\
\hline **Correlation is significant at the 0.01 level (2-tailed) \\
\hline
\end{tabular}

For Eastern Region representing the Semi-deciduous zones recorded a range of 0-441.02 $\mu \mathrm{g} / \mathrm{kg}$. Mean, median and variance of $53.11,4.83$ and $10840.01 \mu \mathrm{g} / \mathrm{kg}$ respectively were recorded. The data set for the Semi-deciduous zone was asymmetrical and light-tailed (2.48 and 6.24 for skewness and kurtosis respectively for Total aflatoxins $\left(A F_{\text {Total }}\right)($ Table 6.0). Ochratoxins levels ranged between 0-97.51 $\mu \mathrm{g} / \mathrm{kg}$. 
Mean, median and variance recorded were $17.75,4.10$ and $827.54 \mu \mathrm{g} / \mathrm{kg}$ respectively. The data set was symmetrical and light-tailed (Skewness and Kurtosis were 1.78 and 1.97 respectively). Significant $(\mathrm{p}<$ 0.01) correlations were recorded between $A F B 1$ and $A F_{\text {Total }}$ likewise $A F_{\text {Total }}$ and OTA (Table 6.1).

Table 6.0

Statistical summary of data obtained from the Eastern Region of Ghana

\begin{tabular}{|lllllll|}
\hline N samples (30) & AFB1 & AFB2 & AFG1 & AFG2 & AFTotal & OTA \\
\hline Mean & 45.14 & 14.22 & 1.93 & 0.55 & 53.14 & 17.75 \\
\hline Std. Error of Mean & 14.79 & 5.23 & 0.94 & 0.27 & 19.00 & 5.25 \\
\hline Median & 5.02 & 0.31 & 0.00 & 0.00 & 4.83 & 4.10 \\
\hline Std. Deviation & 81.00 & 28.67 & 5.13 & 1.47 & 104.12 & 28.77 \\
\hline Variance & 6560.97 & 822.10 & 26.33 & 2.16 & 10840.01 & 827.54 \\
\hline Skewness & 2.22 & 2.06 & 3.61 & 2.56 & 2.48 & 1.78 \\
\hline Std. Error of Skewness & 0.43 & 0.43 & 0.43 & 0.43 & 0.43 & 0.43 \\
\hline Kurtosis & 5.00 & 3.02 & 14.26 & 5.44 & 6.24 & 1.97 \\
\hline Std. Error of Kurtosis & 0.83 & 0.83 & 0.83 & 0.83 & 0.83 & 0.83 \\
\hline Minimum & 0.00 & 0.00 & 0.00 & 0.00 & 0.00 & 0.00 \\
\hline Maximum & 337.30 & 101.00 & 24.80 & 5.51 & 441.02 & 97.51 \\
\hline Percentiles 25 & 0.00 & 0.00 & 0.00 & 0.00 & 0.00 & 0.00 \\
\hline 50 & 5.02 & 0.31 & 0.00 & 0.00 & 4.83 & 4.10 \\
\hline 75 & 47.19 & 9.40 & 1.07 & 0.00 & 47.60 & 20.31 \\
\hline
\end{tabular}

Table 6.1

Associations of mycotoxins (AFB1, AFTotal and OTA) in maize from Eastern Region

\begin{tabular}{|llll|}
\hline & AFB1 & AF $_{\text {Total }}$ & OTA \\
\hline AFB1 & 1.00 & $0.909 * *$ & $0.780^{\star *}$ \\
\hline AFTotal & 0.00 & 0.000 \\
\hline & 1.00 & $0.826^{\star *}$ \\
\hline OTA & & 0.00 \\
\hline$* *$ Correlation is significant at the 0.01 level (2-tailed) \\
\hline
\end{tabular}


The Central Region representing the Coastal Savanna zone recorded a range of 0-139.71 $\mu \mathrm{g} / \mathrm{kg}$. Values of $30.68,20.79$ and $1418.09 \mu \mathrm{g} / \mathrm{kg}$ were recorded as mean, median and variance of the dataset. Skewness and Kurtosis were 1.54 and 1.65 respectively which suggested a normal distribution and light-tailed (Table 7.0). For ochratoxins, a range of $0-38.34 \mu \mathrm{g} / \mathrm{kg}$ was recorded. Mean, median and variance of 4.92 , 0.00 and $80.94 \mu \mathrm{g} / \mathrm{kg}$ with skewness and kurtosis of 0.43 and 6.07 suggestive of a fairly symmetrical and heavy-tailed data set. Total aflatoxins $\left(\mathrm{AF}_{\text {Total }}\right)$ were significantly $(p<0.01)$ correlated with AFB1 and OTA (Table 7.1).

Table 7.0

Statistical summary of data obtained from the Central Region of Ghana

\begin{tabular}{|lllllll|}
\hline N samples (30) & AFB1 & AFB2 & AFG1 & AFG2 & AFTotal & OTA \\
\hline Mean & 25.09 & 5.11 & 0.86 & 0.21 & 30.68 & 4.92 \\
\hline Std. Error of Mean & 5.69 & 1.24 & 0.24 & 0.11 & 6.88 & 1.64 \\
\hline Median & 15.30 & 3.66 & 0.00 & 0.00 & 20.79 & 0.00 \\
\hline Std. Deviation & 31.15 & 6.79 & 1.30 & 0.57 & 37.66 & 8.99 \\
\hline Variance & 970.58 & 46.09 & 1.69 & 0.33 & 1418.09 & 80.94 \\
\hline Skewness & 1.43 & 2.73 & 1.27 & 2.49 & 1.54 & 0.43 \\
\hline Std. Error of Skewness & 0.43 & 0.43 & 0.43 & 0.43 & 0.43 & 0.43 \\
\hline Kurtosis & 0.94 & 9.93 & 0.28 & 4.82 & 1.65 & 6.07 \\
\hline Std. Error of Kurtosis & 0.83 & 0.83 & 0.83 & 0.83 & 0.83 & 0.83 \\
\hline Minimum & 0.00 & 0.00 & 0.00 & 0.00 & 0.00 & 0.00 \\
\hline Maximum & 102.77 & 33.43 & 3.96 & 1.97 & 139.71 & 38.34 \\
\hline Percentiles 25 & 0.00 & 0.00 & 0.00 & 0.00 & 0.00 & 0.00 \\
\hline 50 & 15.31 & 3.66 & 0.00 & 0.00 & 20.79 & 0.00 \\
\hline 75 & 30.28 & 6.44 & 1.62 & 0.00 & 33.63 & 6.18 \\
\hline
\end{tabular}


Table 7.1

Associations of mycotoxins (AFB1, AFTotal and OTA) in maize from Central Region

\begin{tabular}{|c|c|c|c|}
\hline & AFB1 & AFTotal & OTA \\
\hline \multirow[t]{2}{*}{ AFB1 } & 1.00 & $0.991^{\star *}$ & 0.780 ** \\
\hline & & 0.00 & 0.000 \\
\hline \multirow[t]{2}{*}{ AFTotal } & & 1.00 & 0.814 ** \\
\hline & & & 0.000 \\
\hline OTA & & & 1.00 \\
\hline
\end{tabular}

Lastly, the Western Region representing the Rain Forest zone of Ghana ranged between $0-217.41 \mu \mathrm{g} / \mathrm{kg}$. Values of $62.12,48.64$ and $3553.22 \mu \mathrm{g} / \mathrm{kg}$ were recorded as mean, median and variance respectively. Dataset was asymmetrical and light-tailed (skewness and kurtosis were 1.16 and 0.99) (Table 8.0). Quantities of ochratoxins were in the range of $0-85.90 \mu \mathrm{g} / \mathrm{kg}$ with mean, median and variance of 24.19, 21.75 and $591.44 \mu \mathrm{g} / \mathrm{kg}$ respectively. The data was symmetrical and light-tailed (skewness and kurtosis were 0.93 and 0.19 respectively. Associations of Total aflatoxins (AFTotal) with AFB1 and OTA were found to be significant $(p<0.01)$ (Table 8.1). 
Table 8.0

Statistical summary of data obtained from the Western Region of Ghana

\begin{tabular}{|lllllll|}
\hline N samples (30) & AFB1 & AFB2 & AFG1 & AFG2 & AFTotal & OTA \\
\hline Mean & 43.86 & 12.64 & 4.55 & 1.07 & 62.12 & 24.19 \\
\hline Std. Error of Mean & 8.94 & 1.88 & 0.94 & 0.33 & 10.88 & 4.44 \\
\hline Median & 29.91 & 12.44 & 3.58 & 0.00 & 48.64 & 21.75 \\
\hline Std. Deviation & 48.96 & 10.32 & 5.17 & 1.82 & 59.61 & 24.32 \\
\hline Variance & 2396.60 & 106.42 & 26.73 & 3.30 & 3553.22 & 591.44 \\
\hline Skewness & 1.73 & 0.26 & 0.69 & 1.58 & 1.16 & 0.93 \\
\hline Std. Error of Skewness & 0.43 & 0.43 & 0.43 & 0.43 & 0.43 & 0.43 \\
\hline Kurtosis & 3.02 & -1.10 & -1.01 & 1.69 & 0.99 & 0.19 \\
\hline Std. Error of Kurtosis & 0.83 & 0.83 & 0.83 & 0.83 & 0.83 & 0.83 \\
\hline Minimum & 0.00 & 0.00 & 0.00 & 0.00 & 0.00 & 0.00 \\
\hline Maximum & 192.29 & 30.23 & 14.63 & 6.60 & 217.41 & 85.90 \\
\hline Percentiles 25 & 5.70 & 0.00 & 0.00 & 0.00 & 8.70 & 0.00 \\
\hline 50 & 29.91 & 12.44 & 3.58 & 0.00 & 48.64 & 21.75 \\
\hline 75 & 61.42 & 20.98 & 10.21 & 2.28 & 90.37 & 39.22 \\
\hline
\end{tabular}

Table 8.1

Associations of mycotoxins (AFB1, AFTotal and OTA) in maize from Western Region

\begin{tabular}{|llll|}
\hline & AFB1 & AFTotal & OTA \\
\hline AFB1 & 1.00 & $0.900^{* *}$ & $0.655^{\star *}$ \\
\hline AFTotal & 0.00 & 0.000 \\
& 1.00 & $0.680^{\star *}$ \\
\hline OTA & & 0.000 \\
\hline$* *$ Correlation is significant at the 0.01 level (2-tailed) \\
\hline
\end{tabular}

The European Food Safety Authority (EFSA) ${ }^{53}$ and Ghana Standards Authority (GSA) ${ }^{2,54}$ regulatory limits for total aflatoxins $\left(A F_{\text {Total }}\right)$ used were 4 and $10 \mu \mathrm{g} / \mathrm{kg}$ respectively. While ochratoxins (OTA) limits used were 4 and $5 \mu \mathrm{g} / \mathrm{kg}$ respectively for the two institutions ${ }^{55}$ (Table 9) in this study. Locally, both toxins 
quantity limits prescribed by the Ghana Standards Authority are a sub-set of the European Food Safety Authority (EFSA). 
Table 9

Proportions of samples that exceeded $\mathrm{AF}_{\mathrm{Total}}$ and OTA and limits of the European Food Safety Authority (EFSA) and Ghana Standard Authority (GSA)

\begin{tabular}{|c|c|c|c|c|c|c|c|}
\hline & \multirow[t]{2}{*}{ Region } & \multirow[t]{2}{*}{$\begin{array}{l}\text { No. of } \\
\text { samples }\end{array}$} & \multirow[t]{2}{*}{$\begin{array}{l}\text { Overall } \\
\text { Positive }\end{array}$} & \multicolumn{2}{|c|}{$\begin{array}{l}\text { Exceeding EFSA } \\
\text { regulation }\end{array}$} & \multicolumn{2}{|c|}{$\begin{array}{l}\text { Exceeding GSA } \\
\text { regulation }\end{array}$} \\
\hline & & & & Yes (\%) & $\begin{array}{l}\text { Range } \\
(\mu \mathrm{g} / \mathrm{kg})\end{array}$ & Yes (\%) & $\begin{array}{l}\text { Range } \\
(\mu \mathrm{g} / \mathrm{kg})\end{array}$ \\
\hline \multirow[t]{7}{*}{ AFT } & Upper & 30 & 25 & 25 (83.3) & 7.0-106.18 & $23(76)$ & $\begin{array}{l}10.76- \\
106.18\end{array}$ \\
\hline & Northern & 30 & 22 & $21(70)$ & $\begin{array}{l}9.73- \\
285.31\end{array}$ & $18(60)$ & $\begin{array}{l}11.50- \\
285.31\end{array}$ \\
\hline & Ashanti & 30 & 23 & $21(70)$ & $\begin{array}{l}7.98- \\
230.00\end{array}$ & $21(70)$ & $\begin{array}{l}19.40- \\
230.00\end{array}$ \\
\hline & Eastern & 30 & 17 & $16(53.3)$ & $\begin{array}{l}4.72- \\
441.02\end{array}$ & $12(40)$ & $\begin{array}{l}10.70- \\
441.02\end{array}$ \\
\hline & Central & 30 & 20 & $20(66.7)$ & $\begin{array}{l}8.86- \\
139.71\end{array}$ & 19(63.33) & $\begin{array}{l}15.84- \\
139.71\end{array}$ \\
\hline & Western & 30 & 24 & $24(80)$ & $\begin{array}{l}4.27- \\
217.41\end{array}$ & $23(76.67)$ & $\begin{array}{l}10.18- \\
217.41\end{array}$ \\
\hline & Total & 180 & 131 & $127(70.50)$ & $\begin{array}{l}4.27- \\
441.02\end{array}$ & $116(64.44)$ & $\begin{array}{l}10.18- \\
441.02\end{array}$ \\
\hline \multicolumn{8}{|l|}{ OTA } \\
\hline & Upper & 30 & 20 & $18(60.0)$ & $4.88-62.50$ & $17(56.67)$ & $\begin{array}{l}11.86- \\
62.50\end{array}$ \\
\hline & Northern & 30 & 23 & $18(60.0)$ & $4.70-46.77$ & $17(56.67)$ & $\begin{array}{l}3.30- \\
46.77\end{array}$ \\
\hline & Ashanti & 30 & 10 & 10 (33.33) & $5.80-76.05$ & $10(33.33)$ & 5.8-76.05 \\
\hline & Eastern & 30 & 16 & $15(50)$ & $5.50-97.51$ & 16 (53.33) & $\begin{array}{l}5.50- \\
97.51\end{array}$ \\
\hline & Central & 30 & 12 & $11(36.67)$ & $4.00-38.34$ & $8(26.67)$ & $\begin{array}{l}5.98- \\
38.34\end{array}$ \\
\hline & Western & 30 & 22 & $22(73.33)$ & $5.0-85.90$ & $21(70.0)$ & $5.0-85.90$ \\
\hline
\end{tabular}

European Union Food Safety (EFSA) limit for $\mathrm{AF}_{\text {Total }}=4 \mu \mathrm{g} / \mathrm{kg}$

European Union Food Safety (EFSA) limit for OTA $=4 \mu \mathrm{g} / \mathrm{kg}$

Ghana Standards Authority (GSA) limit for $\mathrm{AF}_{\text {Total }}=10 \mu \mathrm{g} / \mathrm{kg}$

Ghana Standards Authority (GSA) limit for OTA $=5 \mu \mathrm{g} / \mathrm{k}$ 


\begin{tabular}{|cccccc|}
\hline Region & $\begin{array}{l}\text { No. of } \\
\text { samples }\end{array}$ & $\begin{array}{l}\text { Overall } \\
\text { Positive }\end{array}$ & $\begin{array}{l}\text { Exceeding EFSA } \\
\text { regulation }\end{array}$ & \multicolumn{2}{l|}{$\begin{array}{l}\text { Exceeding GSA } \\
\text { regulation }\end{array}$} \\
\hline Total & 180 & $94(52.22)$ & $4.00-97.51$ & $89(49.44)$ & $3.30-$ \\
97.51
\end{tabular}

Regarding the frequency and (percentage \%) of positive (Yes) total aflatoxins $\left(\mathrm{AF}_{\text {Total }}\right)$ or ochratoxin $\mathrm{A}$ (OTA) contaminated maize samples above the various permissible limits, the Upper East region recorded an overall positive of $25 / 30$, values of $25(83.3 \%$ ) and ranged between $7.00-106.18 \mu \mathrm{g} / \mathrm{kg}$ and $23(76 \%)$ of range $10.76-106.18 \mu \mathrm{g} / \mathrm{kg}$ tested positive for EFSA and GSA, respectively. For OTA, overall positive of $20 / 30$ were recorded. Values of $18(60 \%)$ within the range of $4.88-62.50 \mu \mathrm{g} / \mathrm{kg}$ and $17(56.67 \%)$ of range $11.86-62.50 \mu \mathrm{g} / \mathrm{kg}$ tested positive for EFSA and GSA respectively.

For Northern, 22/30 were positive with total aflatoxin values of $21(70 \%)$ of range $9.73-285.31 \mu \mathrm{g} / \mathrm{kg}$. For OTA, $23 / 30$ were positive with values of $18(60 \%)$ which ranged between $4.70-46.77 \mu \mathrm{g} / \mathrm{kg}$, and $17(56.67 \%)$ of range $3.30-46.77 \mu \mathrm{g} / \mathrm{kg}$ were recorded as positive for EFSA and GSA respectively.

The Ashanti Region, recorded 23/30 were positive with total aflatoxin values of $21(70 \%)$ within the range of $7.98-230.00 \mu \mathrm{g} / \mathrm{kg}$ and $18(60 \%)$ within the range of $19.40-230.00 \mu \mathrm{g} / \mathrm{kg}$ were recorded. OTA showed $10 / 30$ positive, while 10 (33.33\%) within the range of $5.80-76.05 \mu \mathrm{g} / \mathrm{kg}$ and $10(33.33 \%)$ of range $5.80-$ $76.05 \mu \mathrm{g} / \mathrm{kg}$ for EFSA and GSA.

From the Eastern Region, 17/30 were positive and total aflatoxins values of $16(53.3 \%)$ within a range of $4.72-441.02 \mu \mathrm{g} / \mathrm{kg}$ and $12(40 \%)$ within a range of $10.70-441.02 \mu \mathrm{g} / \mathrm{kg}$ were recorded. OTA levels of $16 / 30$ were positive and $15(50 \%)$ with a range of $5.50-97.51 \mu \mathrm{g} / \mathrm{kg}$ were recorded for EFSA while, 16 (53.33\%) within a range of $5.50-97.51 \mu \mathrm{g} / \mathrm{kg}$ was recorded for GSA.

The Central Region recorded $20 / 30$ as positive, while total aflatoxin values of $20(66.7 \%)$ within the range of $8.86-139.71 \mu \mathrm{g} / \mathrm{kg}$ and $19(63.33 \%)$ within the range of $15.84-139.71 \mu \mathrm{g} / \mathrm{kg}$ were recorded. OTA showed $12 / 30$ as positive while 11 (36.67\%) within the range of $4.00-38.34 \mu \mathrm{g} / \mathrm{kg}$ and $8(26.67 \%)$ of range $5.98-85.90 \mu \mathrm{g} / \mathrm{kg}$ for EFSA and GSA.

Lastly, the Western Region recorded $24 / 30$ positive samples and total aflatoxin values of $24(80 \%)$ within the range of $4.27-217.41 \mu \mathrm{g} / \mathrm{kg}$ and $23(76.67 \%)$ within the range of $10.18-217.41 \mu \mathrm{g} / \mathrm{kg}$ were recorded. OTA showed 22/30 positive and 22 (73.33\%) within the range of 5.0-85.90 $\mu \mathrm{g} / \mathrm{kg}$ and 21 (70.0\%) of the range $5.0-85.90 \mu \mathrm{g} / \mathrm{kg}$ for EFSA and GSA respectively (Table 9). 
Out of a total of 180 samples analyzed for total aflatoxins $\left(\mathrm{AF}_{\text {Total }}\right), 127(70.50 \%)$ surpassed the EFSA limit and were within the range of $4.27-441.02 \mu \mathrm{g} / \mathrm{kg}$ while $116(64.44 \%)$ of samples surpassed GSA limit and ranged between $10.18-441.02 \mu \mathrm{g} / \mathrm{kg}$. Also for OTA, $94(52.22 \%)$ of the samples surpassed the tolerable limit of EFSA were within the range of $4.00-97.51 \mu \mathrm{g} / \mathrm{kg}$, while $89(49.44 \%)$ surpassed the limit of GSA and ranged between 3.30-97.51 $\mu \mathrm{g} / \mathrm{kg}$ (Table 9).

\section{Risk Assessment}

\section{Aflatoxins}

The Estimated Daily Intakes (EDI) of the total aflatoxins in the maize samples from the Upper East Region were $610,180,140,80$, and $60 \mathrm{ng} / \mathrm{Kg} \mathrm{b.w/day} \mathrm{for} \mathrm{infants,} \mathrm{toddlers,} \mathrm{children,} \mathrm{adolescents,} \mathrm{and} \mathrm{adults}$ respectively. The Margin of Exposure (MOE) values recorded were 0.66, 2.22, 2.86, 5.00 and 6.67 respectively. The average potency of the aflatoxins was 0.0323 aflatoxins $\mathrm{ngkg}^{-1} \mathrm{bwday}^{-1}$ and produced cancer risks of $19.70,5.81,4.52,2.58$ and 1.94 respectively (Table 10$)$. 
Table 10

Evaluation of risk for Total Aflatoxins via consumption of maize

\begin{tabular}{|c|c|c|c|c|c|}
\hline Region & Age Category & $\begin{array}{l}\text { Estimated Daily } \\
\text { Intake (EDI) (ng/ } \\
\text { Kg.bw/day) }\end{array}$ & MOE & $\begin{array}{l}\text { Av. Potency (ng } \\
\text { Aflatoxins } \mathrm{kg}^{-1} \text { bwday }^{-1} \text { ) }\end{array}$ & $\begin{array}{l}\text { Cancer } \\
\text { Risk }\end{array}$ \\
\hline \multirow[t]{8}{*}{$\begin{array}{l}\text { Upper } \\
\text { East }\end{array}$} & $\begin{array}{l}\text { Infants }(0-11 \\
\text { mths) }\end{array}$ & 610 & 0.66 & 0.0323 & 19.70 \\
\hline & Toddlers & 180 & 2.22 & 0.0323 & 5.81 \\
\hline & (12-35mths) & & & & \\
\hline & $\begin{array}{l}\text { Children } \\
\text { (36mths-10yrs) }\end{array}$ & 140 & 2.86 & 0.0323 & 4.52 \\
\hline & Adolescents & 80 & 5.00 & 0.0323 & 2.58 \\
\hline & (11-17yrs) & & & & \\
\hline & Adults & 60 & 6.67 & 0.0323 & 1.94 \\
\hline & (18-64yrs) & & & & \\
\hline \multirow[t]{7}{*}{ Northern } & $\begin{array}{l}\text { Infants (0-11 } \\
\text { mths) }\end{array}$ & 900 & 0.40 & 0.0323 & 29.07 \\
\hline & $\begin{array}{l}\text { Toddlers (12- } \\
35 \mathrm{mths})\end{array}$ & 270 & 1.48 & 0.0323 & 8.72 \\
\hline & $\begin{array}{l}\text { Children } \\
\text { (36mths-10yrs) }\end{array}$ & 200 & 2.00 & 0.0323 & 6.46 \\
\hline & Adolescents & 110 & 3.64 & 0.0323 & 3.55 \\
\hline & (11-17yrs) & & & & \\
\hline & Adults & 86 & 4.65 & 0.0323 & 2.78 \\
\hline & (18-64yrs) & & & & \\
\hline Ashanti & $\begin{array}{l}\text { Infants (0-11 } \\
\text { mths) }\end{array}$ & 1150 & 0.35 & 0.0323 & 37.15 \\
\hline \multicolumn{6}{|c|}{ Margin of Exposure-MOE } \\
\hline \multicolumn{6}{|c|}{$\begin{array}{l}\text { Mean aflatoxins- Upper East = } 32.84 \mu \mathrm{g} / \mathrm{kg}, \text { Brong }=48.93 \mu \mathrm{g} / \mathrm{kg} \text {, Ashanti }=62.37 \mu \mathrm{g} / \mathrm{kg} \text {, Eastern }= \\
53.14 \mu \mathrm{g} / \mathrm{kg}\end{array}$} \\
\hline \multicolumn{6}{|c|}{ Central $=30.68 \mu \mathrm{g} / \mathrm{kg}$, Western $=62.12 \mu \mathrm{g} / \mathrm{kg}$} \\
\hline \multicolumn{6}{|c|}{ Daily intake of maize for infants and toddlers were halved $(0.5 \times 0.107 \mathrm{~kg} / \mathrm{day})$} \\
\hline \multicolumn{6}{|c|}{ Daily intake of $0.107 \mathrm{~kg} /$ day was used for children, adolescents and adults } \\
\hline Benchma & Dose Lower limit & $400 \mathrm{ng}$ aflatoxins & day $^{-1}$ & & \\
\hline
\end{tabular}




\begin{tabular}{|c|c|c|c|c|c|}
\hline Region & Age Category & $\begin{array}{l}\text { Estimated Daily } \\
\text { Intake (EDI) (ng/ } \\
\text { Kg.bw/day) }\end{array}$ & MOE & $\begin{array}{l}\text { Av. Potency (ng } \\
\text { Aflatoxins } \mathrm{kg}^{-1} \text { bwday }{ }^{-1} \text { ) }\end{array}$ & $\begin{array}{l}\text { Cancer } \\
\text { Risk }\end{array}$ \\
\hline & $\begin{array}{l}\text { Toddlers (12- } \\
35 \mathrm{mths})\end{array}$ & 340 & 1.18 & 0.0323 & 10.98 \\
\hline & $\begin{array}{l}\text { Children } \\
\text { (36mths-10yrs) }\end{array}$ & 260 & 1.54 & 0.0323 & 8.40 \\
\hline & $\begin{array}{l}\text { Adolescents } \\
(11-17 y r s)\end{array}$ & 140 & 2.86 & 0.0323 & 4.52 \\
\hline & $\begin{array}{l}\text { Adults } \\
\text { (18-64yrs) }\end{array}$ & 110 & 3.64 & 0.0323 & 3.55 \\
\hline Eastern & $\begin{array}{l}\text { Infants (0-11 } \\
\text { mths) }\end{array}$ & 980 & 0.41 & 0.0323 & 31.65 \\
\hline & $\begin{array}{l}\text { Toddler (12- } \\
\text { 35mths) }\end{array}$ & 290 & 1.38 & 0.0323 & 9.37 \\
\hline & $\begin{array}{l}\text { Children (36- } \\
\text { 10yrs) }\end{array}$ & 220 & 1.82 & 0.0323 & 7.11 \\
\hline & $\begin{array}{l}\text { Adolescents } \\
\text { (11-17yrs) }\end{array}$ & 120 & 3.33 & 0.0323 & 3.88 \\
\hline & $\begin{array}{l}\text { Adults } \\
\text { (18-64yrs) }\end{array}$ & 90 & 4.44 & 0.0323 & 2.91 \\
\hline Central & $\begin{array}{l}\text { Infants (0-11 } \\
\text { mths) }\end{array}$ & 570 & 0.70 & 0.0323 & 18.41 \\
\hline & $\begin{array}{l}\text { Toddlers (12- } \\
\text { 35mths) }\end{array}$ & 170 & 2.35 & 0.0323 & 5.49 \\
\hline
\end{tabular}

Margin of Exposure-MOE

Mean aflatoxins- Upper East $=32.84 \mu \mathrm{g} / \mathrm{kg}$, Brong $=48.93 \mu \mathrm{g} / \mathrm{kg}$, Ashanti $=62.37 \mu \mathrm{g} / \mathrm{kg}$, Eastern $=$ $53.14 \mu \mathrm{g} / \mathrm{kg}$

Central $=30.68 \mu \mathrm{g} / \mathrm{kg}$, Western $=62.12 \mu \mathrm{g} / \mathrm{kg}$

Daily intake of maize for infants and toddlers were halved $(0.5 \times 0.107 \mathrm{~kg} / \mathrm{day})$

Daily intake of $0.107 \mathrm{~kg} /$ day was used for children, adolescents and adults

Benchmark Dose Lower limit $=400 \mathrm{ng}$ aflatoxins $\mathrm{kg}^{-1}$ bwday $^{-1}$ 


\begin{tabular}{|c|c|c|c|c|c|}
\hline Region & Age Category & $\begin{array}{l}\text { Estimated Daily } \\
\text { Intake (EDI) (ng/ } \\
\text { Kg.bw/day) }\end{array}$ & MOE & $\begin{array}{l}\text { Av. Potency (ng } \\
\text { Aflatoxins } \mathrm{kg}^{-1} \text { bwday } \\
\end{array}$ & $\begin{array}{l}\text { Cancer } \\
\text { Risk }\end{array}$ \\
\hline & $\begin{array}{l}\text { Children (36- } \\
\text { 10yrs) }\end{array}$ & 130 & 3.08 & 0.0323 & 4.20 \\
\hline & $\begin{array}{l}\text { Adolescents } \\
(11-17 y r s)\end{array}$ & 70 & 5.71 & 0.0323 & 2.26 \\
\hline & $\begin{array}{l}\text { Adults } \\
(18-64 \mathrm{yrs})\end{array}$ & 50 & 8.00 & 0.0323 & 1.62 \\
\hline \multirow[t]{5}{*}{ Western } & $\begin{array}{l}\text { Infants (0- } \\
11 \mathrm{mths})\end{array}$ & 1150 & 0.35 & 0.0323 & 37.15 \\
\hline & $\begin{array}{l}\text { Toddlers (12- } \\
35 \mathrm{mths})\end{array}$ & 340 & 1.18 & 0.0323 & 10.98 \\
\hline & $\begin{array}{l}\text { Children (36- } \\
\text { 10yrs) }\end{array}$ & 260 & 1.54 & 0.0323 & 8.40 \\
\hline & $\begin{array}{l}\text { Adolescents } \\
(11-17 y r s)\end{array}$ & 140 & 2.86 & 0.0323 & 4.52 \\
\hline & $\begin{array}{l}\text { Adults } \\
(18-64 y r s)\end{array}$ & 110 & 3.64 & 0.0323 & 3.55 \\
\hline \multicolumn{6}{|c|}{ Margin of Exposure-MOE } \\
\hline \multicolumn{6}{|c|}{$\begin{array}{l}\text { Mean aflatoxins- Upper East }=32.84 \mu \mathrm{g} / \mathrm{kg} \text {, Brong }=48.93 \mu \mathrm{g} / \mathrm{kg} \text {, Ashanti }=62.37 \mu \mathrm{g} / \mathrm{kg} \text {, Eastern }= \\
53.14 \mu \mathrm{g} / \mathrm{kg}\end{array}$} \\
\hline \multicolumn{6}{|c|}{ Central $=30.68 \mu \mathrm{g} / \mathrm{kg}$, Western $=62.12 \mu \mathrm{g} / \mathrm{kg}$} \\
\hline \multicolumn{6}{|c|}{ Daily intake of maize for infants and toddlers were halved $(0.5 \times 0.107 \mathrm{~kg} /$ day $)$} \\
\hline \multicolumn{6}{|c|}{ Daily intake of $0.107 \mathrm{~kg} /$ day was used for children, adolescents and adults } \\
\hline
\end{tabular}

The Northern Region recorded EDI values of $900,270,200,110$ and $86 \mathrm{ng} / \mathrm{Kg}$ b.w/day for infants, toddlers, children, adolescents, and adults respectively. MOE values of $0.40,1.48,2.00,3.64$ and 4.65. Cancer risks of $29.07,8.72,6.46,3.55$ and 2.78 respectively for these age categories were recorded.

From the Ashanti Region, the EDI values recorded for infants, toddlers, children, adolescents and adults were $1150,340,260,140$, and $110 \mathrm{ng} / \mathrm{Kg}$ b.w/day respectively. MOE values recorded were $0.35,1.18$, $1.54,2.86$, and 3.64 respectively. The average potency was the same while the Cancer risks were 37.15 , $10.98,8.40,4.52$ and 3.55 respectively (Table 10$)$. 
The Eastern Region, recorded EDI values recorded for infants, toddlers, children, adolescents and adults were $980,209,220,120$, and $90 \mathrm{ng} / \mathrm{Kg}$ b.w/day respectively. MOE values recorded were $0.41,1.38,1.82$, 3.33 and 4.44 respectively. The average potency was the same while the Cancer risks were $31.65,9.37$, $7.11,3.88$, and 2.91 respectively (Table 10 ).

From the Central Region, the EDI values recorded for infants, toddlers, children, adolescents and adults were $570,170,130,70$ and $50 \mathrm{ng} / \mathrm{Kg}$ b.w/day respectively. MOE values recorded were $0.70,2.35,3.08$, 5.71 and 8.00 respectively. The average potency was the same while the Cancer risks were 18.41, 5.49, 4.20 , and 1.62 respectively (Table 10 ).

Lastly, for the Western Region, the EDI values recorded for infants, toddlers, children, adolescents and adults were $1150,340,260,140$, and $110 \mathrm{ng} / \mathrm{Kg}$ b.w/day respectively. MOE values recorded were 0.0107 , 0.0307 , and 0.0465 respectively. The average potency was the same while the Cancer risks were 37.15 , $10.98,8.40,4.52$ and 3.55 respectively (Table 10$)$.

\section{Ochratoxins}

Ochratoxins A (OTA) in the maize samples obtained from the various regions produced varied results. From the Upper East Region, the Estimated Daily Intakes (EDI) values recorded were 340, 100, 70, 40, and $30 \mathrm{ng} / \mathrm{Kg}$ b.w/day for infants, toddlers, children, adolescents, and adults respectively. The Margin of Exposure (MOE) values recorded were $0.05,0.18,0.26,0.45$, and 0.60 respectively for the same age categories. The average potency of the ochratoxins was 17.86 ochratoxins $\mathrm{ngkg}^{-1} \mathrm{bwday}^{-1}$ which produced cancer risks of $10.98,3.23,2.26,1.29$, and 0.97 respectively (Table 11 ). 
Evaluation of risk for Ochratoxin A (OTA) via consumption of maize

\begin{tabular}{|c|c|c|c|c|c|}
\hline Region & Age Category & $\begin{array}{l}\text { Estimated Daily } \\
\text { Intake (EDI) (ng/ } \\
\text { Kg.bw/day) }\end{array}$ & MOE & $\begin{array}{l}\text { Av. Potency (ng } \\
\text { ochratoxins } \mathrm{kg}^{-} \\
{ }^{1} \text { bwday }^{-1} \text { ) }\end{array}$ & $\begin{array}{l}\text { Cancer } \\
\text { Risk }\end{array}$ \\
\hline \multirow[t]{7}{*}{$\begin{array}{l}\text { Upper } \\
\text { East }\end{array}$} & $\begin{array}{l}\text { Infants (0-11 } \\
\text { mths) }\end{array}$ & 340 & 0.05 & 0.0323 & 10.98 \\
\hline & $\begin{array}{l}\text { Toddlers }(12- \\
35 \text { mths) }\end{array}$ & 100 & 0.18 & 0.0323 & 3.23 \\
\hline & $\begin{array}{l}\text { Children } \\
\text { (36mths- } \\
10 \mathrm{yrs})\end{array}$ & 70 & 0.26 & 0.0323 & 2.26 \\
\hline & Adolescents & 40 & 0.45 & 0.0323 & 1.29 \\
\hline & (11-17yrs) & & & & \\
\hline & Adults & 30 & 0.60 & 0.0323 & 0.97 \\
\hline & (18-64yrs) & & & & \\
\hline \multirow[t]{7}{*}{ Northern } & $\begin{array}{l}\text { Infants (0-11 } \\
\text { mths) }\end{array}$ & 260 & 0.07 & 0.0323 & 8.40 \\
\hline & $\begin{array}{l}\text { Toddlers (12- } \\
\text { 35mths) }\end{array}$ & 80 & 0.22 & 0.0323 & 2.58 \\
\hline & $\begin{array}{l}\text { Children (36- } \\
\text { 10yrs) }\end{array}$ & 50 & 0.36 & 0.0323 & 1.62 \\
\hline & Adolescents & 30 & 0.60 & 0.0323 & 0.97 \\
\hline & (11-17yrs) & & & & \\
\hline & Adults & 30 & 0.60 & 0.0323 & 0.97 \\
\hline & (18-64yrs) & & & & \\
\hline Ashanti & $\begin{array}{l}\text { Infants (0-11 } \\
\text { mths) }\end{array}$ & 210 & 0.09 & 0.0323 & 6.78 \\
\hline \multicolumn{6}{|c|}{ Margin of Exposure-MOE } \\
\hline \multicolumn{6}{|c|}{$\begin{array}{l}\text { Mean ochratoxins- Upper East }=18.22 \mu \mathrm{g} / \mathrm{kg} \text {, Northern }=14.14 \mu \mathrm{g} / \mathrm{kg} \text {, Ashanti }=11.52 \mu \mathrm{g} / \mathrm{kg} \text {, Eastern } \\
=17.75 \mu \mathrm{g} / \mathrm{kg}\end{array}$} \\
\hline \multicolumn{6}{|c|}{ Central $=4.92 \mu \mathrm{g} / \mathrm{kg}$, Western $=24.19 \mu \mathrm{g} / \mathrm{kg}$} \\
\hline \multicolumn{6}{|c|}{ Daily intake of maize for infants and toddlers were halved $(0.5 \times 0.107 \mathrm{~kg} / \mathrm{day})$} \\
\hline \multicolumn{6}{|c|}{ Daily intake of $0.107 \mathrm{~kg} /$ day was used for children, adolescents, and adults } \\
\hline Benchmar & Dose Lower lim & $=17.86 \mathrm{ng}$ ochrato & $\mathrm{kg}^{-1} \mathrm{bv}$ & & \\
\hline
\end{tabular}




\begin{tabular}{|c|c|c|c|c|c|}
\hline \multirow[t]{5}{*}{ Region } & Age Category & $\begin{array}{l}\text { Estimated Daily } \\
\text { Intake (EDI) (ng/ } \\
\text { Kg.bw/day) }\end{array}$ & MOE & $\begin{array}{l}\text { Av. Potency (ng } \\
\text { ochratoxins kg- } \\
{ }^{1} \text { bwday }^{-1} \text { ) }\end{array}$ & $\begin{array}{l}\text { Cancer } \\
\text { Risk }\end{array}$ \\
\hline & $\begin{array}{l}\text { Toddlers (12- } \\
35 \mathrm{mths})\end{array}$ & 63 & 0.28 & 0.0323 & 2.03 \\
\hline & $\begin{array}{l}\text { Children (36- } \\
\text { 10yrs) }\end{array}$ & 50 & 0.36 & 0.0323 & 1.62 \\
\hline & $\begin{array}{l}\text { Adolescents } \\
(11-17 y r s)\end{array}$ & 30 & 0.60 & 0.0323 & 0.97 \\
\hline & $\begin{array}{l}\text { Adults } \\
\text { (18-64yrs) }\end{array}$ & 20 & 0.89 & 0.0323 & 0.65 \\
\hline \multirow[t]{5}{*}{ Eastern } & $\begin{array}{l}\text { Infants (0-11 } \\
\text { mths) }\end{array}$ & 330 & 0.05 & 0.0323 & 10.66 \\
\hline & $\begin{array}{l}\text { Toddlers (12- } \\
\text { 35mths) }\end{array}$ & 96 & 0.19 & 0.0323 & 3.10 \\
\hline & $\begin{array}{l}\text { Children } \\
\text { (36mths- } \\
\text { 10yrs) }\end{array}$ & 70 & 0.26 & 0.0323 & 2.26 \\
\hline & $\begin{array}{l}\text { Adolescents } \\
\text { (11-17yrs) }\end{array}$ & 40 & 0.45 & 0.0323 & 1.29 \\
\hline & $\begin{array}{l}\text { Adults } \\
\text { (18-64yrs) }\end{array}$ & 30 & 0.60 & 0.0323 & 0.97 \\
\hline \multirow[t]{2}{*}{ Central } & $\begin{array}{l}\text { Infants (0-11 } \\
\text { mths) }\end{array}$ & 90 & 0.20 & 0.0323 & 2.91 \\
\hline & $\begin{array}{l}\text { Toddlers (12- } \\
\text { 35mths) }\end{array}$ & 30 & 0.60 & 0.0323 & 0.97 \\
\hline
\end{tabular}

Margin of Exposure-MOE

Mean ochratoxins- Upper East $=18.22 \mu \mathrm{g} / \mathrm{kg}$, Northern $=14.14 \mu \mathrm{g} / \mathrm{kg}$, Ashanti $=11.52 \mu \mathrm{g} / \mathrm{kg}$, Eastern $=17.75 \mu \mathrm{g} / \mathrm{kg}$

Central $=4.92 \mu \mathrm{g} / \mathrm{kg}$, Western $=24.19 \mu \mathrm{g} / \mathrm{kg}$

Daily intake of maize for infants and toddlers were halved $(0.5 \times 0.107 \mathrm{~kg} / \mathrm{day})$

Daily intake of $0.107 \mathrm{~kg} /$ day was used for children, adolescents, and adults

Benchmark Dose Lower limit $=17.86 \mathrm{ng}$ ochratoxins $\mathrm{kg}^{-1}$ bwday $^{-1}$ 


\begin{tabular}{|c|c|c|c|c|c|}
\hline \multirow[t]{5}{*}{ Region } & Age Category & $\begin{array}{l}\text { Estimated Daily } \\
\text { Intake (EDI) (ng/ } \\
\text { Kg.bw/day) }\end{array}$ & MOE & $\begin{array}{l}\text { Av. Potency (ng } \\
\text { ochratoxins } \mathrm{kg}^{-} \\
{ }^{1} \text { bwday }^{-1} \text { ) }\end{array}$ & $\begin{array}{l}\text { Cancer } \\
\text { Risk }\end{array}$ \\
\hline & $\begin{array}{l}\text { Children } \\
\text { (36mths- } \\
10 \mathrm{yrs})\end{array}$ & 20 & 0.89 & 0.0323 & 0.65 \\
\hline & Adolescents & 10 & 1.79 & 0.0323 & 0.32 \\
\hline & $(11-17 y r s)$ & & & & \\
\hline & $\begin{array}{l}\text { Adults }(18- \\
\text { 64yrs) }\end{array}$ & $8.6 \times 10^{-3}$ & 2059.97 & 0.0323 & $\begin{array}{l}2.78 \times 10^{-} \\
4\end{array}$ \\
\hline \multirow[t]{7}{*}{ Western } & $\begin{array}{l}\text { Infants }(0-11 \\
\text { mths) }\end{array}$ & 450 & 0.04 & 0.0323 & 14.54 \\
\hline & $\begin{array}{l}\text { Toddlers (12- } \\
35 \mathrm{mths})\end{array}$ & 130 & 0.14 & 0.0323 & 4.20 \\
\hline & $\begin{array}{l}\text { Children (36- } \\
\text { 10yrs) }\end{array}$ & 100 & 0.18 & 0.0323 & 3.23 \\
\hline & Adolescents & 60 & 0.30 & 0.0323 & 1.94 \\
\hline & (11-17yrs) & & & & \\
\hline & Adults & 43 & 0.42 & 0.0323 & 1.39 \\
\hline & $(18-64 y r s)$ & & & & \\
\hline \multicolumn{6}{|c|}{ Margin of Exposure-MOE } \\
\hline \multicolumn{6}{|c|}{$\begin{array}{l}\text { Mean ochratoxins- Upper East }=18.22 \mu \mathrm{g} / \mathrm{kg} \text {, Northern }=14.14 \mu \mathrm{g} / \mathrm{kg} \text {, Ashanti }=11.52 \mu \mathrm{g} / \mathrm{kg} \text {, Eastern } \\
=17.75 \mu \mathrm{g} / \mathrm{kg}\end{array}$} \\
\hline \multicolumn{6}{|c|}{ Central $=4.92 \mu \mathrm{g} / \mathrm{kg}$, Western $=24.19 \mu \mathrm{g} / \mathrm{kg}$} \\
\hline \multicolumn{6}{|c|}{ Daily intake of maize for infants and toddlers were halved $(0.5 \times 0.107 \mathrm{~kg} / \mathrm{day})$} \\
\hline \multicolumn{6}{|c|}{ Daily intake of $0.107 \mathrm{~kg} /$ day was used for children, adolescents, and adults } \\
\hline Benchma & Dose Lower lim & $=17.86 \mathrm{ng}$ ochrato & $\mathrm{kg}^{-1} \mathrm{bwd}$ & & \\
\hline
\end{tabular}

The Northern Region recorded EDI values of $260,80,50,30$ and $30 \mathrm{ng} / \mathrm{Kg} \mathrm{b} . \mathrm{w} /$ day for infants, toddlers, children, adolescents, and adults respectively. MOE values of $0.07,0.22,0.36,0.60$ and 0.60 were obtained respectively for the same age categories. Cancer risks values of $8.40,2.58,1.62,0.97$, and 0.97 respectively were obtained.

From the Ashanti Region, the EDI values recorded for infants, children and adolescents and adults were $1150,63,50,30$ and $20 \mathrm{ng} / \mathrm{Kg}$ b.w/day respectively. MOE values recorded were $0.35,0.28,0.36,0.60$, and 
0.89. The average potency was the same for Upper East while the Cancer Risks were 37.15, 2.03, 1.62, 0.97, and 0.65. (Table 11).

From the Eastern Region, the EDI values recorded for infants, toddlers, children, adolescents and adults were $330,96,70,40$ and $30 \mathrm{ng} / \mathrm{Kg}$ b.w/day respectively. MOE values recorded were 0.05, 0.19, 0.26, 0.45, and 0.60 respectively. The average potency was the same while the Cancer risks were $10.66,3.10,2.26$, 1.29 , and 0.97 respectively (Table 11 ).

From the Central Region, the EDI values recorded for infants, toddlers, children, adolescents and adults were 90, 30, 20, 10 and 8.6×10-3. Likewise, MOE values recorded were 0.20, 0.60, 0.89, 1.79 and 2059.97. The average potency was the same while Cancer Risks were $2.91,0.97,0.65,0.32$, and $2.78 \times 10^{-4}$ (Table 11).

Lastly, for the Western Region, the EDI values recorded for infants, toddlers, children, adolescents and adults were 450, 130, 100, 60, and $43 \mathrm{ng} / \mathrm{Kg}$ b.w/day respectively. MOE values recorded were $0.04,0.14$, $0.18,0.30$ and 0.42 respectively. The average potency was the same as other regions while the cancer risks were $14.54,4.20,3.23,1.94$, and 1.39 respectively (Table 11 ).

\section{Discussion}

The discrete incidence of ochratoxins and aflatoxins in foodstuff is quite common in cereals and is a worldwide problem during pre-and post-harvest stages ${ }^{56}$. However, the concomitant occurrence of these mycotoxins has not been researched adequately in Africa. In this study, a range of 0-97.51 $\mu \mathrm{g} / \mathrm{kg}$ (mean $48.76 \mu \mathrm{g} / \mathrm{kg}$ ) of ochratoxins was obtained and were comparable to other previous studies globally. Nalle et al ${ }^{57}$ reported a mean value of $20.385 \mu \mathrm{g} / \mathrm{kg}$ in corn grains and corn products from different sources in West Timor, Indonesia. Kamala et al ${ }^{58}$ reported a range of $16-73 \mu \mathrm{g} / \mathrm{kg}$ OTA concentration in maize samples from Tanzania. Values of ranges $0.12-0.59 \mu \mathrm{g} / \mathrm{kg}$ and $1.70-19.5 \mu \mathrm{g} / \mathrm{kg}$ have been reported by Kara et al ${ }^{59}$ in cereal flour samples from Turkey and by De Giromalo et al ${ }^{60}$ for cereals from Italy respectively, Again, Temba et al ${ }^{61}$ also reported levels of $19.5 \mu \mathrm{g} / \mathrm{kg}$. Veldman et al ${ }^{62}$ demonstrated a total of $16.7 \%$ of maize samples originating from Holland contaminated by OTA with an average level of $73 \mu \mathrm{g} / \mathrm{kg}$. From Brazil, Sekiyama et al ${ }^{63}$ recorded levels between the range of $0-64 \mu \mathrm{g} / \mathrm{kg}$.

Greater quantities of ochratoxins have been reported in maize from other studies worldwide. Recently, ul Hassan ${ }^{64}$ reported ochratoxins (OTA) levels that ranged from 2.14-214 $\mu \mathrm{g} / \mathrm{kg}$ which was detected in $71 \%$ of commercially grown maize samples in Pakistan. Makun et al ${ }^{65}$ reported that samples of maize showed the highest levels of OTA were in the range of ND to $139.2 \mu \mathrm{g} / \mathrm{kg}$ in Nigeria.

Conversely, Iram et al ${ }^{66}$ did not detect ochratoxins in maize samples obtained from Punjab, Pakistan. Adebajo et al ${ }^{67}$ also detected OTA in corn-based snacks in Nigeria only at toxicologically significant levels. The co-occurrence of different mycotoxins in one commodity created by fungal genera is common 68. The permissible limit of OTA recognized by FAO/WHO Joint Committee Experts on Food Additives is 
$100 \mathrm{ng} / \mathrm{kg} /$ week and 14ng/kg/day, whereas European Food Safety re-established $120 \mathrm{ng} / \mathrm{kg}$ of OTA, which is nearly $17.1 \mathrm{ng} / \mathrm{kg} 47$.

Ochratoxins have been implicated in a variety of adverse health effects both in humans and in animals suggested to be reaching from renal, neuro-, immuno-, and embryo-toxicity to muta- or teratogenicity ${ }^{69}$. OTA was proven as a renal carcinogen in rodents ${ }^{70}$, nevertheless its transferability to humans is still not clear ${ }^{71}$. Its carcinogenicity has been adopted to be related with genetic changes leading to a new assessment so that OTA can also be considered as genotoxic/mutagenic ${ }^{72}$. The high presence of OTA might be attributed to other fungal species that have not yet been explored or due to other pieces.

Aflatoxins levels recorded in this study was in the range of $0-441.02 \mu \mathrm{g} / \mathrm{kg}$ which is within the range of values reported by Adebajo et al ${ }^{67}$ for values between the ranges $25-770 \mathrm{ppb}, 15-1070 \mathrm{ppb}$, and 10-160 ppb for corn, corn cake, and corn roll snack respectively in Nigeria.

Recently, Kortei et al ${ }^{2}$ also reported aflatoxins levels of range $0-445.01 \mu \mathrm{g} / \mathrm{kg}$ from maize samples obtained from different agro-ecological zones across Ghana. Aflatoxin quantities of 692 and $945 \mathrm{ng} \mathrm{g}^{-1}$ from maize samples obtained from Fumesua and Ejura in Ghana respectively by ${ }^{73}$. From Eastern and Central Kenya, Lewis et $\mathrm{al}^{74}$ reported greater quantities of aflatoxin $>1000 \mathrm{ppb}$ in maize samples from contamination due to aflatoxin of commercial maize products during an outbreak of acute aflatoxicosis. Dadzie et al ${ }^{73}$ recorded Total aflatoxins levels in the samples per community were in the range of below limit of detection (LOD) to $692 \mathrm{ng} / \mathrm{g}, 23 \mathrm{ng} / \mathrm{g}, 945 \mathrm{ng} / \mathrm{g}$, and $112 \mathrm{ng} / \mathrm{g}$ for Fumesua, Wenchi, Ejura, and Akomadan, respectively.

Lower aflatoxin levels have been reported in other studies. de Souza et al ${ }^{75}$ reported quantities as low as 0-16 in Brazilian maize and maize-based foods. Total aflatoxin values of $50.234,70.102$, and 30.943 $\mathrm{ng} / \mathrm{g}$ were, respectively obtained from three composite samples taken from the Ejura market was reported by ${ }^{76}$. Danso et $\mathrm{al}^{77}$ reported aflatoxin levels of $2.9-3.4 \mathrm{ppb}$ in all markets in the minor season maize samples, but levels ranging from 38.2 to $64.0 \mathrm{ppb}$ were found in the major season samples. Total aflatoxin levels of $82.9 \mathrm{ppb}, 48.9 \mathrm{ppb}$, and $48.9 \mathrm{ppb}$ were recorded for maize samples stored in polypropylene sack, hermetic bags, and local crib respectively by ${ }^{78}$.

The variation in contamination levels could be attributed to speckled infection levels of the toxigenic fungus genera, Aspergillus (esp. flavus) owing to their ubiquitous nature, infect maize grains on the field even before harvest ${ }^{79,80}$. Ghana is reliant on rain-fed agriculture which is coupled with high temperatures and unavailability of regular rains, the crop is left under stress which predisposes the crop to fungal invasion ${ }^{81}$ during the growth cycle. This may explain the presence of aflatoxins on maize grains before storage.

There were significant correlations between AFtotal and OTA. Likewise, AFB1 and AFtotal in this study. These observations corroborate the findings of some previous researchers ${ }^{63,64,66,82}$. The co-existence of 
two or more fungi and their subsequent mycotoxins production in an environment suggests a possible non-antagonistic metabolites interaction additionally, the probable effect of combined exposure to aflatoxins with other mycotoxins in foodstuffs could be additive or antagonistic.

At variance with our observation, Imperato et al ${ }^{82}$ reported that among food products analyzed in Italy, dried vine fruits were mainly contaminated with OTA and less with AFs. Discovered from pertinent literature, there is an inverse correlation between AFB1 and OTA. To buttress this claim, ${ }^{83}$ observed, no AFB1 was found in dried vine fruits, while OTA was detected at high levels. In addition, Dimitrokallis et al 84 reported that OTA inhibits AFB1 production by Aspergillus species in a related study.

The different categorizations of the biosphere (agro-ecological zones) presage different growth conditions for the proliferation of fungi. Brzonkalik et al ${ }^{85}$ as well Garcia et al ${ }^{86}$ emphasized mycotoxin production is dependent on species or/and strain, which is affected by the growth substrate and environmental conditions. de Souza et $\mathrm{al}^{75}$ and Kortei et al ${ }^{88}$ also explained co-existence of fungal strains on a substrate can affect both the level of mycotoxin production and the toxicity of the contaminated grains resulting in additive and synergistic effects when tested Nonetheless, data on multiple mixtures is very rare ${ }^{87}$.

The relatively high aflatoxin (AF) and ochratoxin (OTA) concentrations in maize grains suggested favorable environmental conditions for the growth of these fungi ${ }^{88,89} .{ }^{90}$ noted that Penicillium spp. grow well between $0-30^{\circ} \mathrm{C}$ and have been found to produce ochratoxin $A$ this may explain the high incidence of this mycotoxin. Furthermore, Magan et al ${ }^{89}$ also emphasized fungal contamination in cereals is influenced by two main factors. Firstly, by initial high moisture content in crops or late harvesting of crops in rural areas, and secondly, the lack or poor storage facilities characterized by poor ventilation, high temperatures, and humidity.

Regular monitoring and pre-and post-harvest control measures can be used to control mycotoxins by enhancing the resistance of the crop against incursive fungi through plant breeding or genetic engineering which are laborious and time-consuming. Effective, sustainable, and universally applicable pre-harvest intervention strategies are needed. Proper field management practices such as the use of resistant varieties, timely planting, fertilizer application, weed control, insect control, and avoiding drought and nutritional stress could reduce mycotoxins ${ }^{91}$. Other options are the biological control by using nontoxigenic strains to competitively displace toxigenic fungi ${ }^{92}$.

\section{Risk assessment.}

Kuiper-Goodman ${ }^{93}$ highlighted that risk estimations are computed to envisage the adverse health implications of mycotoxin exposure and guide food regulators to set limits for these toxins in foodstuffs.

Risk assessment results obtained in this study were comparable to published findings of Blanckson and Mills ${ }^{94}$ as they reported Total aflatoxins EDI values of range $0.005-1.054 \mu \mathrm{gkg}^{-1} \mathrm{bwd}^{-1}$ and $0.004-0.838$ 
$\mu \mathrm{kgg}^{-1} \mathrm{bwd}^{-1}$ for infants and young children respectively in infant cereal-based formula and were risky for children to consume in Ghana.

The Estimated Daily Intakes (EDI) of the total aflatoxins in the maize samples recorded by Kortei et al ${ }^{2}$ were 109.7, 58.8, 33.08, and $25.2 \mathrm{\mu g} \mathrm{Kg} \mathrm{bw}^{-1}$ day $^{-1}$ for infants, children, adolescents, and adults with Margin of Exposure (MOE) values of 4.73, 8.79, 15.63 and 20.51 respectively.

Exposure assessment carried out by Omari and Anyebuno ${ }^{95}$ showed that the minimum and maximum daily AFs exposures were 0.044 and $2.805 \mu \mathrm{g} / \mathrm{kg} \mathrm{bw} / \mathrm{d}$, respectively for weanimix (infant complementary food prepared from maize) from rural households; these rates for complementary food purchased from urban shops were 0.014 and $0.55 \mu \mathrm{g} / \mathrm{kg}$ bw/d, respectively. The chances of liver cancer development would increase to 0.6 per year if infants were fed on complementary food prepared in rural households with a minimum AF level of $7.9 \mu \mathrm{g} / \mathrm{kg}$.

In Guangzhou China, Zhang et al ${ }^{96}$ reported EDI values of range $0.02-0.04$ respectively for the age ranges of $3-6,7-17,18-59$, and above 60 yrs for maize and products. All their computed MOE values were below the safe threshold of 10,000 and so risk analysis results showed that most of the lower bound MOE values ranged from 10 to 100 , indicating a concern for risk management. Age-group analysis suggested close attention is paid to the $3 \sim 6$ years of age group, whose MOE value was the lowest. Their results reflected those preschool children might have the highest risk of being exposed to AF. Their results agreed with our findings.

The MOE values (995-860 at mean and 336 at 95th percentile exposure) and cancer potency estimates, based on the current exposure levels indicated a potential health concern for Turkish adults was reported by ${ }^{97}$. Li et al ${ }^{98}$ pointed from a Chinese survey data, that the average daily intake of AFB1 from maize in the high-risk area was $184.1 \mu \mathrm{g}$, and the probable daily intake is estimated to be $3.68 \mu \mathrm{g} \mathrm{kg}^{-1} \mathrm{bw} \mathrm{day}^{-1}$.

Chun et al ${ }^{99}$ estimated excess cancer risk values to liver cancer incidence by ingestion of these foods for AFB1 were calculated to be $5.78 \times 10^{-6}$ for individuals negative for hepatitis $B$ and $1.48 \times 10^{-4} \mathrm{mg} \mathrm{kg}^{-1}$ bw day ${ }^{-1}$ for individuals positive for hepatitis $B$ in Korea.

Various interventions have been established to combat aflatoxin biosynthesis and accumulation, ranging from preharvest to dietary interventions. Simply avoiding or reducing consumption of foods that are frequently contaminated with aflatoxin has shown effectiveness in reducing liver cancer mortality in one population ${ }^{100}$.

Advocacy on the strict compliance to good agricultural practice (GAP), good manufacturing practice (GMP) as well as good hygiene practice (GHP) which are critical ingredients to alleviate the formation of aflatoxins in the field as well as during storage of foodstuffs, must be strengthened. By impeding the aflatoxins formation in foods, there is the protection of both public health and the prevention of economic 
losses. Monitoring foods prone to fungal infection and the presence of mycotoxins regularly is cautious to assess the public level of awareness.

\section{Conclusion}

Based on the results obtained in this study, per the permissible limits set by the European Food Safety Authority (EFSA) (2 and $4 \mu \mathrm{g} / \mathrm{kg}$ ) and the Ghana Standards Authority (GSA) (5 and 10-15 $\mu \mathrm{g} / \mathrm{kg}$ ), it can be construed that out of the 180 samples analyzed for total aflatoxins $\left(A F_{\text {Total }}\right), 68 \%$ exceeded the limits of EFSA whereas $58 \%$ exceeded for GSA limits. In the case of $A_{F B}, 71 \%$ of samples exceeded EFSA limits while $64 \%$ exceeded GSA limits. For OTA, 94(52.22\%) of samples exceeded the tolerable limit of EFSA, while $89(49.44 \%)$ exceeded the limits of GSA.

Human health risk assessment for ochratoxin A as well as aflatoxins exposure via maize consumed in the different regions of Ghana by infants, children, and adolescents, and adults showed a significant adverse health risk in all the age categories of humans since all calculated values for Margin of Exposure (MOE) were less than 10,000 for both aflatoxins and ochratoxins. This study scratches the surface of a dire situation that calls for attention by all stakeholders involved in mitigating the harmful effects associated with these hazardous mycotoxin exposures to humans.

\section{Declarations}

\section{Data Availability}

All data supporting this study are included in the article and its supplementary material.

\section{References}

1. Ekpa, O., Palacios-Rojas, N., Kruseman, G., Fogliano, V. \& Linnemann, A. R. Sub-Saharan African maize-based foods-processing practices, challenges and opportunities. Food Reviews International, 35, 609-639 (2019).

2. Kortei, N. K. et al. The occurrence of aflatoxins and human health risk estimations in randomly obtained maize from some markets in Ghana. Sci. Rep, 11, 1-13 (2021).

3. Khalil, O. A., Hammad, A. A. \& Sebaei, A. S. Aspergillus flavus and Aspergillus ochraceus inhibition and reduction of aflatoxins and ochratoxin A in maize by irradiation. Toxicon(2021).

4. Zummo, N. \& Scott, G. Interaction of Fusarium moniliforme and Aspergillus flavus on kernel infection and aflatoxin contamination in maize ears. Plant Dis, 76, 771-773 (1992).

5. FAO. FAOSTAT online statistical service. (2006).

6. Nuss, E. T. \& Tanumihardjo, S. A. Maize: a paramount staple crop in the context of global nutrition. Comprehensive reviews in food science and food safety, 9, 417-436 (2010). 
7. Adegbeye, M. J. et al. Mycotoxin toxicity and residue in animal products: Prevalence, consumer exposure and reduction strategies-A review., 177, 96-108 (2020).

8. Agriopoulou, S., Stamatelopoulou, E. \& Varzakas, T. Advances in occurrence, importance, and mycotoxin control strategies: Prevention and detoxification in foods. Foods, 9, 137 (2020).

9. Agbetiameh, D. et al. Prevalence of aflatoxin contamination in maize and groundnut in Ghana: population structure, distribution, and toxigenicity of the causal agents. Plant disease, 102, 764-772 (2018).

10. Klingelhöfer, D. et al. Ochratoxin-Characteristics, influences and challenges of global research., 114, 107230 (2020).

11. Kpodo, K. A. Fusaria and Fumonisins in Maize and Fermented Maize Products from Ghana,Royal Veterinary and Agricultural University, Department of Dairy and Food\&\#8230

12. Bui-Klimke, T. R. \& Wu, F. Ochratoxin A and human health risk: A review of the evidence. Critical reviews in food science and nutrition, 55, 1860-1869 (2015).

13. Organization, W. H. Safety evaluation of certain food additives and contaminants Vol. 68 (World Health Organization, 2008).

14. Haighton, L. A., Lynch, B. S., Magnuson, B. A. \& Nestmann, E. R. A reassessment of risk associated with dietary intake of ochratoxin A based on a lifetime exposure model. Critical reviews in toxicology, 42, 147-168 (2012).

15. El Khoury, A., Atoui, A. \& Ochratoxin, A. general overview and actual molecular status. Toxins, 2, 461493 (2010).

16. Heussner, A. H. \& Bingle, L. E. Comparative ochratoxin toxicity: A review of the available data. Toxins, 7, 4253-4282 (2015).

17. Kumar, P. et al. Ochratoxins in food and feed: Occurrence and its impact on human health and management strategies. Toxicon(2020).

18. Cappozzo, J. et al. Occurrence of ochratoxin A in infant foods in the United States. Journal of food protection, $80,251-256(2017)$.

19. Lv, L., Li, D., Cui, C., Zhao, Y. \& Guo, Z. Nuclease-aided target recycling signal amplification strategy for ochratoxin A monitoring. Biosensors and Bioelectronics, 87, 136-141 (2017).

20. Pfohl-Leszkowicz, A., Manderville, R. A. \& Ochratoxin, A. An overview on toxicity and carcinogenicity in animals and humans. Molecular nutrition \& food research, 51, 61-99 (2007).

21. Singh, P. K., Singh, R. P., Singh, P. \& Singh, R. L. Food Hazards: Physical, Chemical, and Biological. In: Food Safety and Human Health 15-65(Elsevier, 2019).

22. Bbosa, G. S., Kitya, D. \& Ogwal-Okeng, J. Aflatoxins metabolism, effects on epigenetic mechanisms and their role in carcinogenesis(2013).

23. Authority, E. F. S. Outcome of a public consultation on the draft risk assessment of aflatoxins in food.Report No.2397-8325, (Wiley Online Library, 2020). 
24. Ostry, V., Malir, F., Toman, J. \& Grosse, Y. Mycotoxins as human carcinogens-the IARC Monographs classification. Mycotoxin research, 33, 65-73 (2017).

25. van Egmond, H. P., Schothorst, R. C. \& Jonker, M. A. Regulations relating to mycotoxins in food. Analytical and bioanalytical chemistry, 389, 147-157 (2007).

26. Bankole, S. \& Adebanjo, A. Mycotoxins in food in West Africa: current situation and possibilities of controlling it. African journal of Biotechnology, 2, 254-263 (2003).

27. Authority, E. F. S. Opinion of the Scientific Committee on a request from EFSA related to Exposure Assessments. EFSA Journal, 3, 249 (2005).

28. Sun, G. et al. Co-contamination of aflatoxin B1 and fumonisin B1 in food and human dietary exposure in three areas of China. Food additives and contaminants, 28, 461-470 (2011).

29. Huong, B. T. M., Brimer, L. \& Dalsgaard, A. Dietary exposure to aflatoxin B1, ochratoxin A and fuminisins of adults in Lao Cai province, Viet Nam: A total dietary study approach. Food and chemical toxicology, 98, 127-133 (2016).

30. Kortei, N. K. et al. MICROBIOLOGICAL QUALITY EVALUATION : A CASE STUDY. African Journal of Food, Agriculture, Nutrition and Development 20, 16669-16688 (2020).

31. Rhebergen, T. et al. Climate, soil and land-use based land suitability evaluation for oil palm production in Ghana. European Journal of Agronomy, 81, 1-14 (2016).

32. Chan, D., MacDonald, S., Boughtflower, V. \& Brereton, P. Simultaneous determination of aflatoxins and ochratoxin $A$ in food using a fully automated immunoaffinity column clean-up and liquid chromatography-fluorescence detection. Journal of Chromatography A, 1059, 13-16 (2004).

33. Stroka, J. \& Anklam, E. New strategies for the screening and determination of aflatoxins and the detection of aflatoxin-producing moulds in food and feed. TrAC Trends in Analytical Chemistry, 21, 90-95 (2002).

34. dos Santos, J. S. et al. Natural occurrence of deoxynivalenol in wheat from Paraná State, Brazil and estimated daily intake by wheat products. Food Chem, 138, 90-95 (2013).

35. Chain, E. P. et al. o. C. i. t. F. Risk assessment of aflatoxins in food. EFSA Journal 18, e06040(2020).

36. EFSA Panel on Dietetic Products. N. \& Allergies. Scientific Opinion on the appropriate age for introduction of complementary feeding of infants. EFSA Journal, 7, 1423 (2009).

37. Lartey, A., Manu, A., Brown, K., Peerson, J. \& Dewey, K. Predictors of growth from 1 to 18 months among breast-fed Ghanaian infants. European journal of clinical nutrition, 54, 41-49 (2000).

38. Abubakari, A., Kynast-Wolf, G. \& Jahn, A. Prevalence of abnormal birth weight and related factors in Northern region, Ghana. BMC pregnancy and childbirth, 15, 1-8 (2015).

39. Glover-Amengor, M. et al. Nutritional status of children 0-59 months in selected intervention communities in northern Ghana from the africa RISING project in 2012. Archives of Public Health, 74, $1-12$ (2016).

40. Abeshu, M. A., Lelisa, A. \& Geleta, B. Complementary feeding: review of recommendations, feeding practices, and adequacy of homemade complementary food preparations in developing countries- 
lessons from Ethiopia. Frontiers in nutrition, 3, 41 (2016).

41. Biritwum, R., Gyapong, J. \& Mensah, G. The epidemiology of obesity in Ghana. Ghana medical journal, 39, 82 (2005).

42. Organization, W. H. WHO child growth standards: length/height-for-age, weight-for-age, weight-forlength, weight-for-height and body mass index-for-age: methods and development (World Health Organization, 2006).

43. Afrifa-Anane, E., Agyemang, C., Codjoe, S. N. A., Ogedegbe, G. \& Aikins, A. d.-G. The association of physical activity, body mass index and the blood pressure levels among urban poor youth in Accra, Ghana. BMC public health, 15, 1-9 (2015).

44. Walpole, S. C. et al. The weight of nations: an estimation of adult human biomass. BMC public health, 12, 1-6 (2012).

45. Adetunji, M. C., Alika, O. P., Awa, N. P., Atanda, O. O. \& Mwanza, M. Microbiological quality and risk assessment for aflatoxins in groundnuts and roasted cashew nuts meant for human consumption. Journal of toxicology 2018 (2018).

46. Joint, F. \& Additives, W. E. C. o. F. Safety evaluation of certain mycotoxins in food. (Rome:FAO, 2001).

47. Authority, E. F. S. Opinion of the Scientific Panel on contaminants in the food chain [CONTAM] related to ochratoxin A in food. EFSA journal, 4, 365 (2006).

48. Groopman, J. D., Cain, L. G., Kensler, T. W. \& Harris, C. C. Aflatoxin exposure in human populations: measurements and relationship to cancer. CRC Critical reviews in Toxicology, 19, 113-145 (1988).

49. Shephard, G. S. Risk assessment of aflatoxins in food in Africa. Food Additives and Contaminants, 25, 1246-1256 (2008).

50. Joint, F., Additives, W. E. C., O., F. \& Organization, W. H. Evaluation of certain food additives and contaminants: forty-ninth report of the Joint FAO/WHO Expert Committee on Food Additives (World Health Organization, 1999).

51. Abesig, J., Chen, Y., Wang, H., Sompo, F. M. \& Wu, I. X. Prevalence of viral hepatitis B in Ghana between 2015 and 2019: A systematic review and meta-analysis. PloS one, 15, e0234348 (2020).

52. Ofori-Asenso, R. \& Agyeman, A. A. Hepatitis B in Ghana: a systematic review \& meta-analysis of prevalence studies (1995-2015). BMC infectious diseases, 16, 1-15 (2016).

53. Commission, E. Commission Regulation (EC) No 1881/2006 of 19 December 2006 setting maximum levels for certain contaminants in foodstuffs. Official Journal of the European Union, 364, 5-24 (2006).

54. Omari, R. et al. Aflatoxins and Their Management in Ghana: A Situational Analysis. Report No. 25503359, (FARA Research Report 5 (20), 2020).

55. Joint, F. \& WHO and from the 68th meeting of the Joint FAO/WHO Expert Committee on Food Additives (JECFA). Matters of interest arising from FAO and. 40th Session. Beijing, China: Joint FAO/WHO Food Standards Programme Codex Committee on Food Additives (2008). 
56. Iqbal, S. Z., Asi, M. R., Zuber, M., Akhtar, J. \& Saif, M. J. Natural occurrence of aflatoxins and ochratoxin A in commercial chilli and chilli sauce samples., 30, 621-625 (2013).

57. Nalle, C., Helda, H., Masus, B. \& Malo, J. Nutritional Evaluation of Sago of Gebang Tree (Corypha utan Lamk) from Different Locations in West Timor-Indonesia for Broilers. Tropical Animal Science Journal, 44, 48-61 (2021).

58. Kamala, A. et al. Multiple mycotoxin co-occurrence in maize grown in three agro-ecological zones of Tanzania., 54, 208-215 (2015).

59. Kara, G. N., Ozbey, F. \& Kabak, B. Co-occurrence of aflatoxins and ochratoxin A in cereal flours commercialised in Turkey., 54, 275-281 (2015).

60. De Girolamo, A. et al. Performance evaluation of LC-MS/MS methods for multi-mycotoxin determination in maize and wheat by means of international Proficiency Testing. TrAC Trends in Analytical Chemistry, 86, 222-234 (2017).

61. Temba, M., Njobeh, P. \& Kayitesi, E. Storage stability of maize-groundnut composite flours and an assessment of aflatoxin B1 and ochratoxin A contamination in flours and porridges., 71, 178-186 (2017).

62. Veldman, A., Borggreve, G., Mulders, E. \& Van de Lagemaat, D. Occurrence of the mycotoxins ochratoxin A, zearalenone and deoxynivalenol in feed components. Food Addit. Contam, 9, 647-655 (1992).

63. Sekiyama, B. L., Ribeiro, A. B., Machinski, P. A. \& Machinski Junior, M. Aflatoxins, ochratoxin A and zearalenone in maize-based food products. Brazilian Journal of Microbiology, 36, 289-294 (2005).

64. ul Hassan, S. W. et al. Unusual pattern of aflatoxins and ochratoxin in commercially grown maize varieties of Pakistan., 182, 66-71 (2020).

65. Makun, H. A. et al. Natural occurrence of ochratoxin A in some marketed Nigerian foods., 31, 566571 (2013).

66. Iram, W., Anjum, T., Abbas, M. \& Khan, A. M. Aflatoxins and ochratoxin A in maize of Punjab, Pakistan. Food Additives \& Contaminants: Part B, 7, 57-62 (2014).

67. Adebajo, L., Idowu, A. \& Adesanya, O. Mycoflora, and mycotoxins production in Nigerian corn and corn-based snacks., 126, 183-192 (1994).

68. Xing, F. et al. Distribution and variation of fungi and major mycotoxins in pre-and post-nature drying maize in North China Plain. Food control, 80, 244-251 (2017).

69. Duarte, S., Pena, A. \& Lino, C. A review on ochratoxin A occurrence and effects of processing of cereal and cereal derived food products. Food microbiology, 27, 187-198 (2010).

70. Program, N. T. Toxicology and carcinogenesis studies of ochratoxin A (CAS No. 303-47-9) in F344/N rats (gavage studies). National Toxicology Program technical report series 358, 1-142(1989).

71. Malir, F. et al. 50 years of research. Toxins, 8, 191 (2016).

72. Pfohl-Leszkowicz, A. \& Manderville, R. A. An update on direct genotoxicity as a molecular mechanism of ochratoxin a carcinogenicity. Chemical research in toxicology, 25, 252-262 (2012). 
73. Dadzie, M. et al. Distribution of Aspergillus flavus and aflatoxin accumulation in stored maize grains across three agro-ecologies in Ghana., 104, 91-98 (2019).

74. Lewis, L. et al. Aflatoxin contamination of commercial maize products during an outbreak of acute aflatoxicosis in eastern and central Kenya. Environmental health perspectives, 113, 1763-1767 (2005).

75. de Souza, M. L. M. et al. Cooccurrence of mycotoxins in maize and poultry feeds from Brazil by liquid chromatography/tandem mass spectrometry. The Scientific World Journal 2013 (2013).

76. Akowuah, J. O., Mensah, L. D., Chan, C. \& Roskilly, A. Effects of practices of maize farmers and traders in Ghana on contamination of maize by aflatoxins (Case study of Ejura-Sekyeredumase Municipality, 2015).

77. Danso, J. et al. Post-harvest insect infestation and mycotoxin levels in maize markets in the Middle Belt of Ghana. Journal of Stored Products Research, 77, 9-15 (2018).

78. Benson-Obour, R. et al. Evaluation of aflatoxin contamination of stored maize in the Brong-Ahafo region of Ghana.Julius-Kühn-Archiv,1091-1098(2018).

79. Kucharek, T. \& Raid, R. Some diseases of corn in Florida. Florida Cooperative Extension Service Institute of Food and Agricultural Science University of Florida. Circular-1130. Gainesville, FL, USA 15(2000).

80. Munkvold, G. P., Hurburgh, C. R., Meyer, J. R., Loy, D. \& Robertson, A. Aflatoxins in corn (lowa State University, University Extension Ames, IA, 2005).

81. Cotty, P. J. \& Jaime-Garcia, R. Influences of climate on aflatoxin producing fungi and aflatoxin contamination. International journal of food microbiology, 119, 109-115 (2007).

82. Imperato, R., Campone, L., Piccinelli, A. L., Veneziano, A. \& Rastrelli, L. Survey of aflatoxins and ochratoxin a contamination in food products imported in Italy., 22, 1905-1910 (2011).

83. MacDonald, S. et al. Ochratoxin A in dried vine fruit: method development and survey. Food Addit. Contam, 16, 253-260 (1999).

84. Dimitrokallis, V., Meimaroglou, D. \& Markaki, P. Study of the Ochratoxin A effect on Aspergillus parasiticus growth and aflatoxin B1 production. Food and chemical toxicology, 46, 2435-2439 (2008).

85. Brzonkalik, K., Herrling, T., Syldatk, C. \& Neumann, A. The influence of different nitrogen and carbon sources on mycotoxin production in Alternaria alternata. International journal of food microbiology, $147,120-126$ (2011).

86. Garcia, D. et al. Impact of cycling temperatures on Fusarium verticillioides and Fusarium graminearum growth and mycotoxins production in soybean. Journal of the Science of Food and Agriculture, 92, 2952-2959 (2012).

87. Klarić, M. Å., Rašić, D. \& Peraica, M. Deleterious effects of mycotoxin combinations involving ochratoxin A. Toxins, 5, 1965-1987 (2013). 
88. Kortei, N. K., Odamtten, G. T., Obodai, M. \& Wiafe-Kwagyan, M. Mycofloral profile and the radiation sensitivity (D10 values) of solar dried and gamma irradiated Pleurotus ostreatus (Jacq. Ex. Fr.) Kummer fruitbodies stored in two different packaging materials. Food science \& nutrition, 6, 180188 (2018).

89. Magan, N., Hope, R., Cairns, V. \& Aldred, D. Post-harvest fungal ecology: impact of fungal growth and mycotoxin accumulation in stored grain. In: Epidemiology of mycotoxin producing fungi723730(Springer, 2003).

90. Pitt, J. I. \& Hocking, A. D. Methods for isolation, enumeration and identification. In: Fungi and food spoilage 21-57 (Springer, 1997).

91. Hell, K. \& Mutegi, C. Aflatoxin control and prevention strategies in key crops of Sub-Saharan Africa. African Journal of Microbiology Research, 5, 459-466 (2011).

92. Hell, K., Mutegi, C. \& Fandohan, P. Aflatoxin control and prevention strategies in maize for SubSaharan Africa. Julius-Kühn-Archiv,534(2010).

93. Kuiper-Goodman, T. Uncertainties in the risk assessment of three mycotoxins: aflatoxin, ochratoxin, and zearalenone. Canadian journal of physiology and pharmacology, 68, 1017-1024 (1990).

94. Blankson, G. \& Mill-Robertson, F. Aflatoxin contamination and exposure in processed cereal-based complementary foods for infants and young children in greater Accra, Ghana., 64, 212-217 (2016).

95. Omari, R. \& Anyebuno, G. Risk Assessment of Aflatoxins in Maize-Groundnuts Complemen-tary Foods Consumed by Ghanaian Infants. Journal of food quality and hazards control(2020).

96. Zhang, W. et al. Probabilistic risk assessment of dietary exposure to aflatoxin B 1 in Guangzhou, China. Scientific reports, 10, 1-9 (2020).

97. Kabak, B. Aflatoxins in foodstuffs: Occurrence and risk assessment in Turkey. Journal of Food Composition and Analysis, 96, 103734 (2021).

98. Li, F. Q., Yoshizawa, T., Kawamura, O., Luo, X. Y. \& Li, Y. W. Aflatoxins and fumonisins in corn from the high-incidence area for human hepatocellular carcinoma in Guangxi, China. Journal of Agricultural and Food Chemistry, 49, 4122-4126 (2001).

99. Chun, H., Ok, H., Kim, H., Hwang, J. B. \& Chung, D. H. Risk assessment of aflatoxins in food products consumed in South Korea. In: 13th World Congress of Food Science \& Technology 2006. 458-458.

100. Wu, F. Global impacts of aflatoxin in maize: trade and human health. World Mycotoxin Journal, 8 , 137-142 (2015).

\section{Figures}




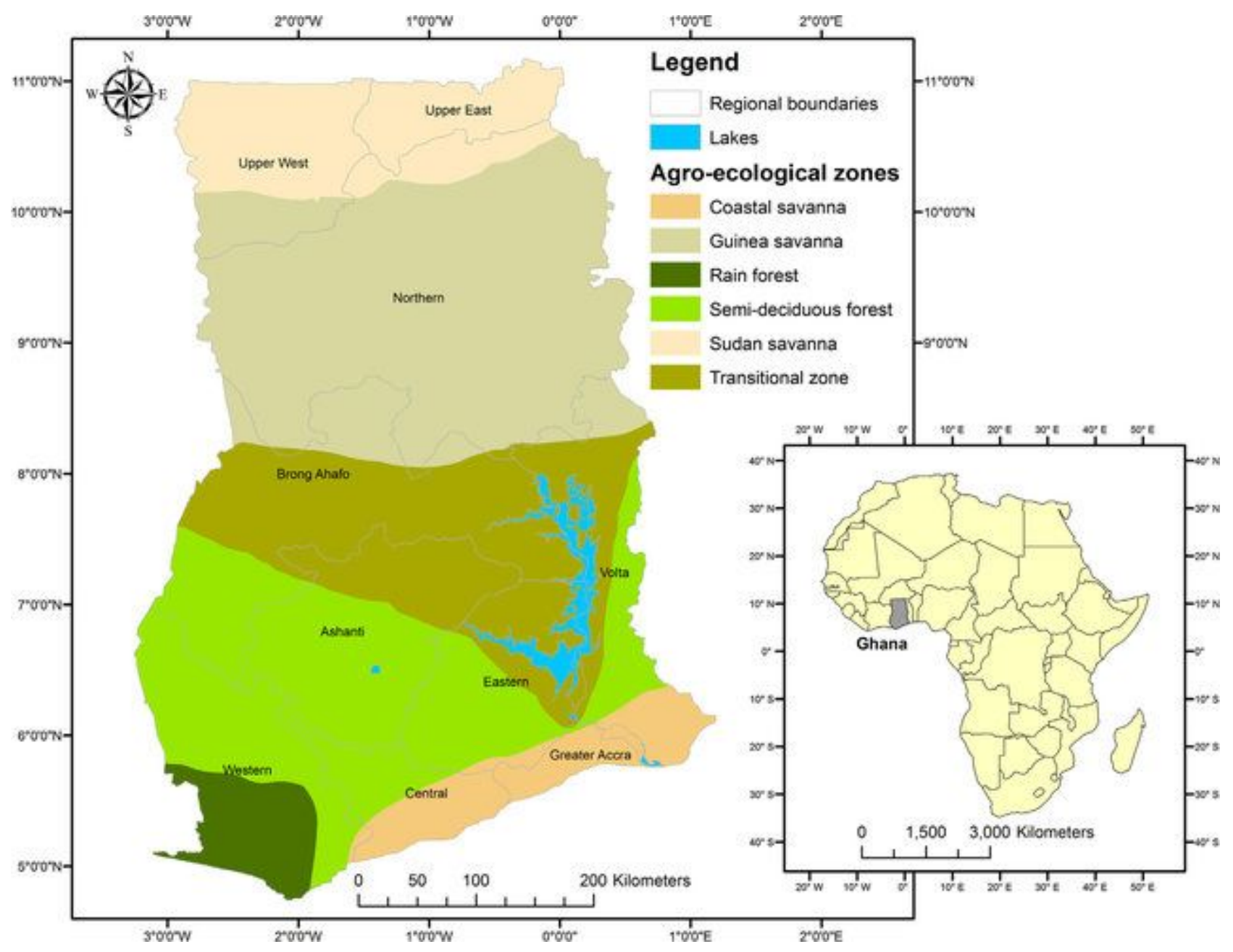

Figure 1

Map of Ghana showing the different agro-ecological zones where the maize grains were sampled (Adapted from 31) 